\title{
UN TEMPLO DE TRADICIÓN NEOCLÁSICA EN EL NOR TE DE ÁFRICA. LA IGLESIA DE LA INMACULADA CONCEPCIÓN DE CHAFARINAS
}

\author{
ANTONIO BRAVO NIETO \\ Profesor-Tutor UNED \\ Instituto de Cultura Mediterránea
}

La Iglesia de la Inmaculada Concepción de las islas Chafrinas es, sin duda, el principal edificio de este archipiélago a pesar de su actual mal estado de conservación. Su monumentalidad r efleja que en el momento de su constr ucción existieron unas perspectivas muy optimistas sobre el desarrollo futuro de su población. Sin embargo, las previsiones que soñaban con la conversión de las Chafarinas en un importante enclave no se hicieron realidad, aunque llegó a contar en sus mejor es tiempos con una pob lación cifrada entre 500 y 700 per sonas. Actualmente la iglesia per manece como una extraordinar ia construcción, tan descontextualizada como interesante, al reflejar un momento histórico de la presencia española en el norte de África.

\section{La ocupación de las islas y la sacralización del espacio}

El día 6 de enero de 1848, festividad de los Reyes Magos, se produjo la ocupación de las islas Chafarinas. Ésta se materializó con el desembarco de la flota preparada al efecto, y ese mismo día el cura ecónomo y vicario interino de la iglesia parroquial de Melilla, Dr. Bartolomé de Fuentes, puso a las islas bajo la advocación de laAdoración de los Reyes Magos, y las bautizó una a una, dándoles por disposición del Gobier no los nombres de Congreso, Isabel II y Rey.

Desde este año se suceden un importante número de obras, sobre todo de fortificación, centradas en su mayor parte en la isla de Isabel II. Sin embargo la edificación de una capilla se haría esperar por el carácter de urgencia que equerían las obras de defensa. En uno de los planos más antiguos que se conservan de 
esta isla ${ }^{1}$, aparece ya reflejada la zona alta con el polbado y un proyecto de iglesia, aunque se dibuja su planta transversalmente a como se construyó años más tarde. Lo que sí par ece claro es que desde el pr incipio se toma la $\mathrm{r}$ eferencia del lugar aproximado donde debía construirse y que la iglesia presidiría la plaza principal de la isla. Es curioso que en la toponimia aplicada a las islas, a sus obras y lugares, no se utilizan ya referentes religiosos relativos a santos, como había sido la norma durante los siglos anteriores.

En esos momentos iniciales se pensaba en un futuro muy esperanzador para las islas, pero como acertada e incisivamente escribió Rafael Pezzi ${ }^{2}$ en 1893 "pasado el calor de la toma de posesión, nadie volvió a ocuparse de los presidios”.

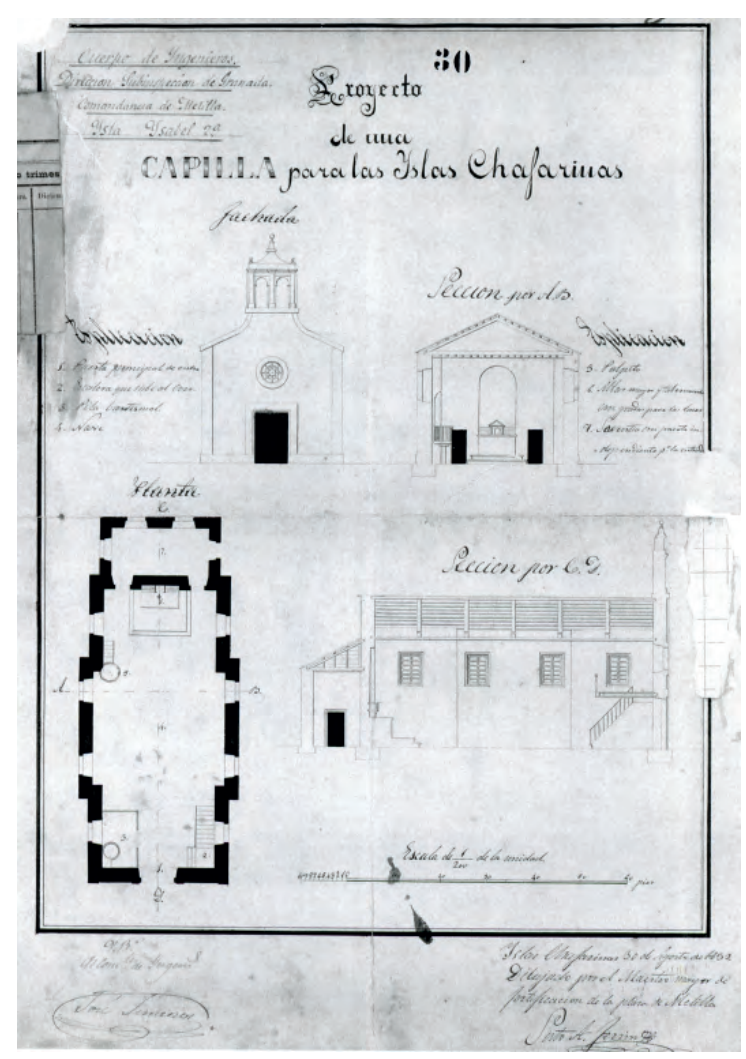

Proyecto de una capilla para las islas Chafarinas. AHM.

1 Plano de la Isla de Isabel $2^{a}$ con el proyecto de fortificación permanente hecho por el capitán D. Francisco de Alemany, 24 de septiembre de 1848. ML-03-14. IHCM.

2 PEZZI, Rafael (1893). Los presidios menores de África y la influencia española en el RifTip. Fortanet. 


\section{El primer proyecto de la iglesia de la Inmaculada Concepción de las Chafarinas}

El primer proyecto que conocemos de una iglesia da ta de 1852, cuatro años después de la ocupación ${ }^{3}$, dibujado por el maestro mayor de fortificación de la Plaza de Melilla,Sixto A, Ferrín ${ }^{4}$, dando su visto bueno el ingeniero José Jiménez y del Corral $^{5}$.

Según el proyecto, Ferrín diseña una capilla de gran sencillez y que presenta bastantes similitudes con la estr uctura general del templo actual, así como diferentes detalles tanto de la fachada como de la disposición de elementos que son idénticos: así podemos ver en el número de vanos, en la situación y diseño del coro, la fachada con rosetón, el altar mayor y tabernáculo, la estructura de las sacristías, la situación del púlpito y otros detalles menores.

Todas estas similitudes nos parecen indicar que el proyecto de Ferrín sirvió de inspiración para la realización de la iglesia definitiv a, o bien que ambos proyectos respondían a un programa común determinado ya con antelación.

\section{José María Aparici y el proyecto definitivo}

Pero los años que corren entre 1852 y 1857 fueron momentos de incertidumbre y de pocas obras en las islas, e incluso en 1856 la Junta de Defensa Permanente del Reino había pr opuesto su abandono. Por esa razón no se hizo nada en estos años, a pesar de que en 1855 ya estaba presupuestada la fábrica de la iglesia.

3 Proyecto de una capilla para las islas Chaf arinas, $\mathrm{n}^{\circ}$ 30. Cuerpo de ingenieros, Dirección Subispección de Granada, Comandancia de Melilla, Isla de Isabel II. Fachada, Sección por A_B, Planta, Sección por C_D. Escala 1/200 pies, y escala gráfica, Islas Chafarinas 30 de agosto de 1852. Dibujado por el maestro mayor de for tificación de la Plaza de Melilla, Sixto A, Ferrín, $V^{\circ} B^{\circ}$ el comandante de ingenieros José Jiménez. Archivo Histórico de Melilla.

4 Archivo General Militar de Sego via, Expedientes Personales. Sixto A. Ferrín nació en San Cristóbal de Canto (Pontevedra) el 6 de agosto de 1820, siendo maestro de obras en el Ferrol desde el 5 de agosto de 1845. En abril de 1851, al ascender a maestro mayor de $2^{\text {a }}$ clase fue enviado a Melilla, donde estuvo encargado de las obras de Chafarinas hasta su marcha en septiembre de 1852. Posteriormente recibió destino en Cartagena, en donde estuvo hasta 1867 fecha en la que se fue a Madrid, lugar donde se jubiló en 1880 .

5 José Jiménez y del Corral, fue ingeniero que nació en los últimos años del siglo XVIII,ingresando en el servicio del Cuerpo de Ingenieros el 8 de enero de 1818. Después de cursar sus estudios en la escuela de Arévalo, forma parte de la $4^{\text {a }}$ promoción que finaliza sus estudios el 19 de marzo de 1830, fecha en la que inicia su carrera profesional en el mundo de la ingeniería militar. 
El proyecto definitivo del templo tiene que ver con un ingeniero de gran prestigio, José María de Aparici y Biedma ${ }^{6}$, que desde 1857 defiende la conservación de las Chafarinas y que consigue finalmente realizar un amplio programa de obras, dentro del cual remodela y consolida la plaza principal de la isla en torno a la iglesia.

Aparici señalaba en 1857 que las islas no tenían iglesia "que los católicos celebran los ritos de su culto en una baraca que ni siquiera está bendita y que los cadáveres se enterraban en un campo sin cerca”.

Por estas y otras muchas razones, el Ingeniero General decide encargar un proyecto general de for tificación el 7 de Agosto de 1857, y José María Aparici realiza una memoria de las obras que consideraba necesarias, que firma el $23 \mathrm{de}$ septiembre de ese mismo año ${ }^{7}$. Una de las primeras preocupaciones de Aparici fue computar la mano de obra necesar ia para su proyecto (que cifraba en 120 operarios y 400 confinados), así como la previsión de su alojamiento y los servicios necesarios para su estancia en las islas.

José María Aparici pretendía consolidar la incipiente trama urbana del poblado definiendo la plaza donde se habría de constrir la Iglesia, aunque para ello se debían realizar los desmontes necesarios ${ }^{8}$. En la citada memoria de 1857, este ingeniero nos señala que tanto la capilla como el cementer io estaban proyectados y figuraban ya en el presupuesto de 1855, siendo consideradas ambas como obras de urgencia. La iglesia se sitúa en este pr oyecto cerrando la plaza por el Norte y respecto al cementerio, la Comandancia de Ingenieros pensaba que debía construirse en la isla del Reg, sobre todo razonando que esta isla se uniría con Isabel II mediante un dique.

El plano enumera las obras que se debían $\mathrm{r}$ ealizar ${ }^{9}$ : se proyectan nuevos pabellones que definían la citada plaza, a derecha e izquierda, determinando la

6 Aparici y Biedma, José. Ingeniero militar. Nació enValencia el 22 de febrero de 1824. Ingresó en la Academia de Guadalajara en 1838. En 1874 era br igadier de Ingenieros, y en 1886 asciende a Mariscal de Campo. Murió en 1894.

7 La memoria las firma José María Aparici el 23 de septiembre de 1857. 651/8, IHCM.

8 Signatura 651/8. Granada 23 de septiembre de 1857, José María Aparici, IHCM.

9 Plano de la Ysla de Isabel $2^{a}$, que acompaña al presupuesto formado por el comandante D. José María Aparici de las obras que ha proyectado con arreglo a las instrucciones del Exmo Señor Ingeniero General del 7 de agosto de 1857.ML-03-18. Granada 25 de septiembre de 1857, dibujado por el comandante José María Aparici. $V^{\circ} \mathrm{B}^{\circ}$ el coronel director subinspector into. ManuelValdés. Hay otros dos muy similares de 16 de octubre. Dibujados por RicardoValdivieso, IHCM, Melilla, nº 405, y ML-03-17. 
idea de un pob lado con cier ta ordenación urbana, regido por una iglesia que todavía no se había construido.

La capilla (que figura con el númeo 10 en ese plano) aparece con un tamaño más reducido que el actual, por lo que deducimos que a pesar de estar y a presupuestada, no se contaba aún con el proyecto definitivo, que sería por tanto posterior a 1857 .

Dos años después, el mismo ingeniero y Juan Manuel Lombera realizan un ambicioso proyecto de fortificación de las islas ${ }^{10}$, en el que aparece dibujada en planta y en alzado la nueva iglesia. Este edificio figura como obra aprobada, por lo que su construcción parecía inminente, y por tanto debemos reseñarla como un proyecto realizado por el propio José María Aparici durante su estancia en Melilla ${ }^{11}$.
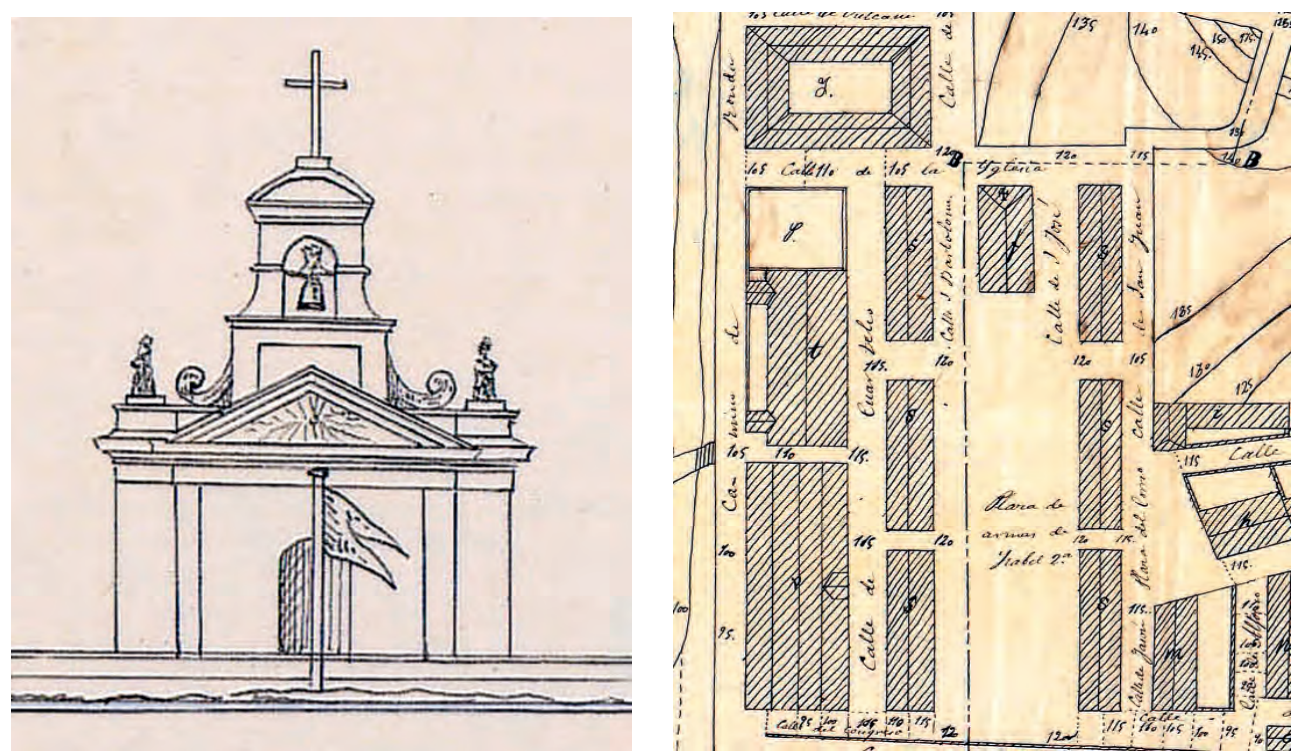

Fachada de la iglesia y planta de la plaza de la iglesia en: Sector de Proyecto de fortificación, edificios y puerto de las islas Chafarinas, 10 de enero de 1859, Lombera y Aparici, AGMM, sig 4-5-9-1-2 y ML-03-10.

10 Proyecto de for tificación, edificios y puer to de las islas Chaf arinas, 10 de ener o de 1859 , Lombera y Aparici, AGMM, sig 4-5-9-12. 74 folios. Contiene varios planos.

11 Plano de la isla de Isabel $2^{\text {a }}$ como quedará después de concluidos los edificios appbados y las defensas proyectadas por los coroneles T.C. Don Juan Manuel Lombera y Comandante Don José María Aparici. Madrid, 16 de abril de 1859, Dibujado por el dibujante sargento $2^{\circ}$ del Regimiento José Pajarero. Comprobado Juan Manuel Lombera. ML-03-10, IHCM. 
La fachada que aparece en este pr oyecto es realmente una idealización, pero en lo general marca la idea de lo que estaba proyectado por entonces, destacando la base neoclásica del conjunto y algunos detalles que, sin embargo, nos remitirían a un concepto más barroco de sus formas.

Por otra parte, en el plano de planta,la iglesia ya figura rigiendo la plaza de armas de la isla, su principal espacio urbano y sin duda más significativo, por lo que se estaba definiendo el principal edificio del archipliélago y su volumen corresponde ya con la obra que finalmente se realiza ${ }^{12}$. La iglesia sacraliza el espacio y lo dota de un fuer te significado de rotunda implantación en la incipiente trama urbana de Isabel II y paisajística de todo el conjunto isleño.

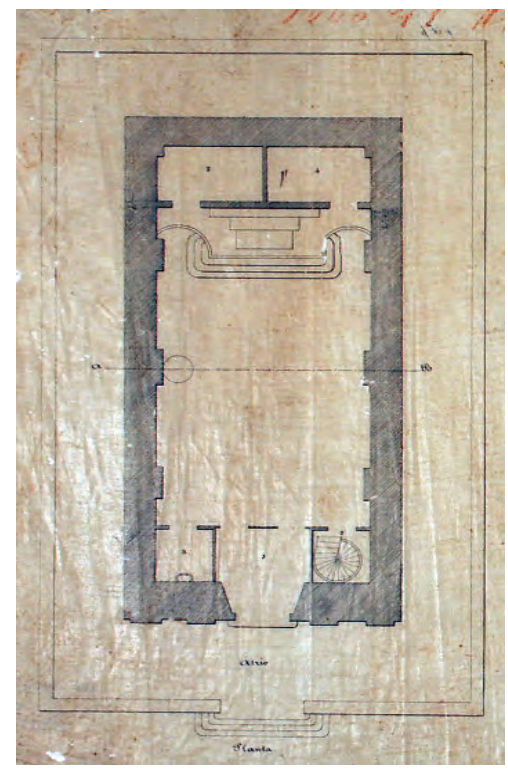

Plano, s/f, IHCM, Melilla, $n^{\circ}$ 406. Sin fecha, pero 1859-1862.

En 1863, el mismo Aparici escribía, refiriéndose al año de 1862:"considerando de primera necesidad la terminación de la capilla y pabellones de los curas y escuelas de niños no siendo suficiente el pr esupuesto se hizo indispensable la formación de uno nuevo ascendiendo a $56.290 \mathrm{r}$. y cuyos gastos se consideran

12 Memoria descriptiva que acompaña al proyecto y presupuesto de las obras que para la defensa de las islas consideran indispensab les los coroneles Juan Manuel Lombera y J osé María Aparici, 1859, Madrid 8 de abril de 1859.651/12, IHCM. 
pertenecientes a los mismos fondos que el anterior. Se ha dado principio al cementerio construyendo un muro de cerca con su cer radura y rastrillo, igualmente un osario en su interior" (el cementerio al que se refiere es el que estuvo situado en la isla de Isabel II). "En la capilla se ha constr uido su campanario, la escalera de subida al coro, la balaustrada de éste, el pavimento de mármol de toda ella, varias puertas, ventanas y vidrieras y alambreras para estas, construyendo igualmente la mesa del altar y v erja del presbiterio como así mismo el atrio con su verja de hierro y cancela de los mismos, habiéndose terminado la sacristía con lo que ha quedado concluido el edificio".

"Para comprender desde luego la importancia de la iglesia construida, basta tener presente que en las islas Chafirinas sufrían sus habitantes el sentimiento de ser suprimido todo el culto público y que cual si estuviesen en campaña, solo los días festivos y permitiéndolo el tiempo oían al aire libre una misa que celebraba el sacerdote en una pequeña baraca construida de madera vieja indigna de todo punto del sagrado objeto a que estaba destinada. Hoy en la referida iglesia pueden celebrarse los divinos oficios con el decoro que la religión exige y con la dignidad propia de un pueblo español situado a la vista de dos naciones extranjeras a cuyos moradores era preciso ocultar antes el local destinado para el culto". Por otra parte, la casa de curas se construía junto a la escuela, porque se pensaba que el clero debía "vigilar la moral" 13.

José María Aparici nos certifica por tanto en este documento tanto su autoría sobre el proyecto, su dirección en las obras y la fecha de finalización, $1862^{14}$.

Sin embargo, y de forma sorprendente, la iglesia no llegaría a inaugurarse hasta el 12 de octubre de 1865, debido a que hasta esa fedha no se había completado la compra de los ornamentos religiosos para el culto ${ }^{15}$.

${ }^{13}$ IHCM. 651 / 16 Melilla 3 de julio de 1863. Memoria descriptiva de los trabajos ejecutados en esta plaza durante el año pasado de 1862 y primer semestre del actual de 1863.

${ }^{14}$ José Luis Blasco (1992) nos señala que fue construida en 1862, sufragada por la Junta Municipal y Capitanía General de la costa de Granada ("Iglesias de laVicaría de África. Las islas Chafarinas. La iglesia de la Inmaculada Concepción de las Chafarinas". El Telegrama de Melilla, 11 de octubre de 1992).

15 En La Correspondencia de España, de 16-07-1865, se dice que "hace 5 años se terminó la capilla y los católicos tienen que celebrar misa en una barraca sin que haya sido bendecida”. La España, de 3-111865, ya daba cuenta de la bendición del templo. 


\section{El cementerio y su traslado}

El cementerio de las islas estaba situado en una zona al noroeste de Isabel II, y en el plan de obras ya estudiado se intentó dignificarlo construyéndole una cerca para delimitar su espacio. Existía, como ya hemos visto, la propuesta de llevarlo a la isla del Rey, pero va a permanecer en Isabel II durante mucho tiempo, figurando como un espacio singular en toda la cartografía de la época ${ }^{16}$. En 1889 incluso se plantea la construcción de un pequeño cementerio hebreo adosado al cristiano, costeado por Jacob Salama ${ }^{17}$ y diseñado por el maestr o de obras militares Julián Argos Salinas

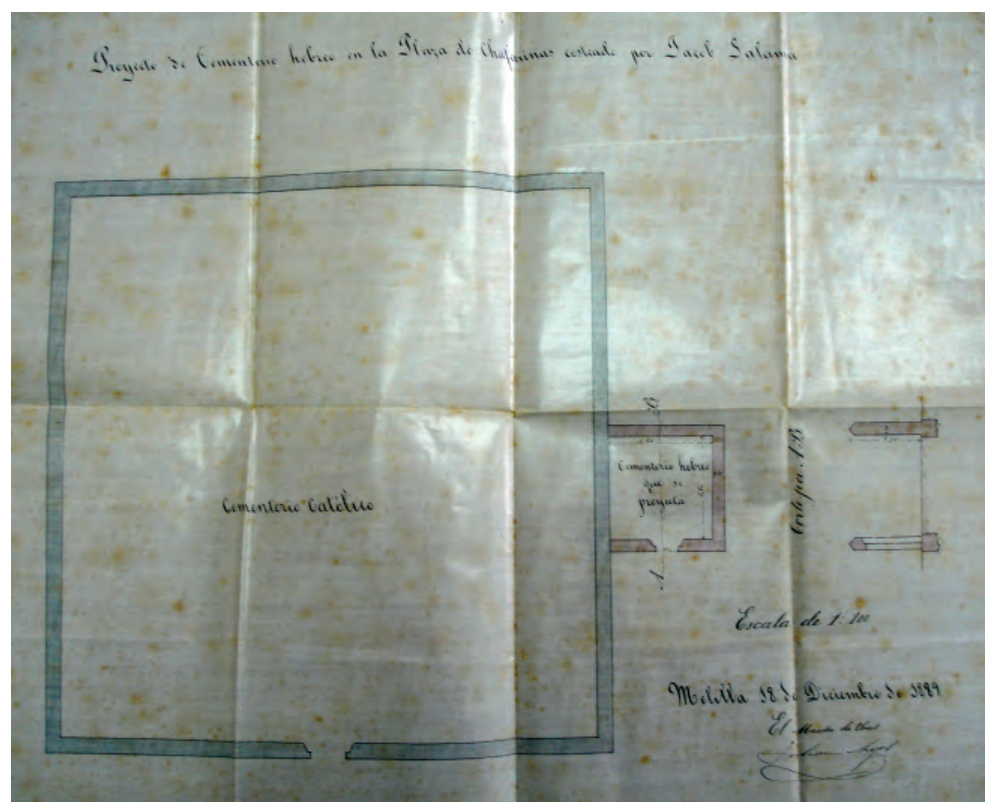

Proyecto de cementerio hebreo en la plaza de Chafarinas, 18 de diciembre de 1889. IHCM, Segovia.

Gracias a este plano conocemos mejor su estnctura, aunque está determinada por una g ran sencillez, al presentar una planta cuadrangular con cerca y puerta de entrada, tal y como la diseñó Aparici en 1862.

16 Plaza de Chafarinas, Plano de la isla de Isabel II con la indicación de la constr ucción que se solicita. Melilla 1 de octubre de 1887. Ingeniero comandante Eligio Souza. IHCM, Segovia.

17 1889, Proyecto de cementerio hebreo en la plaza de Chafarinas costeado por Jacob Salama, Melilla 18 de diciembre de 1889, el maestro de obras Julián Argos. IHCM, Segovia. 


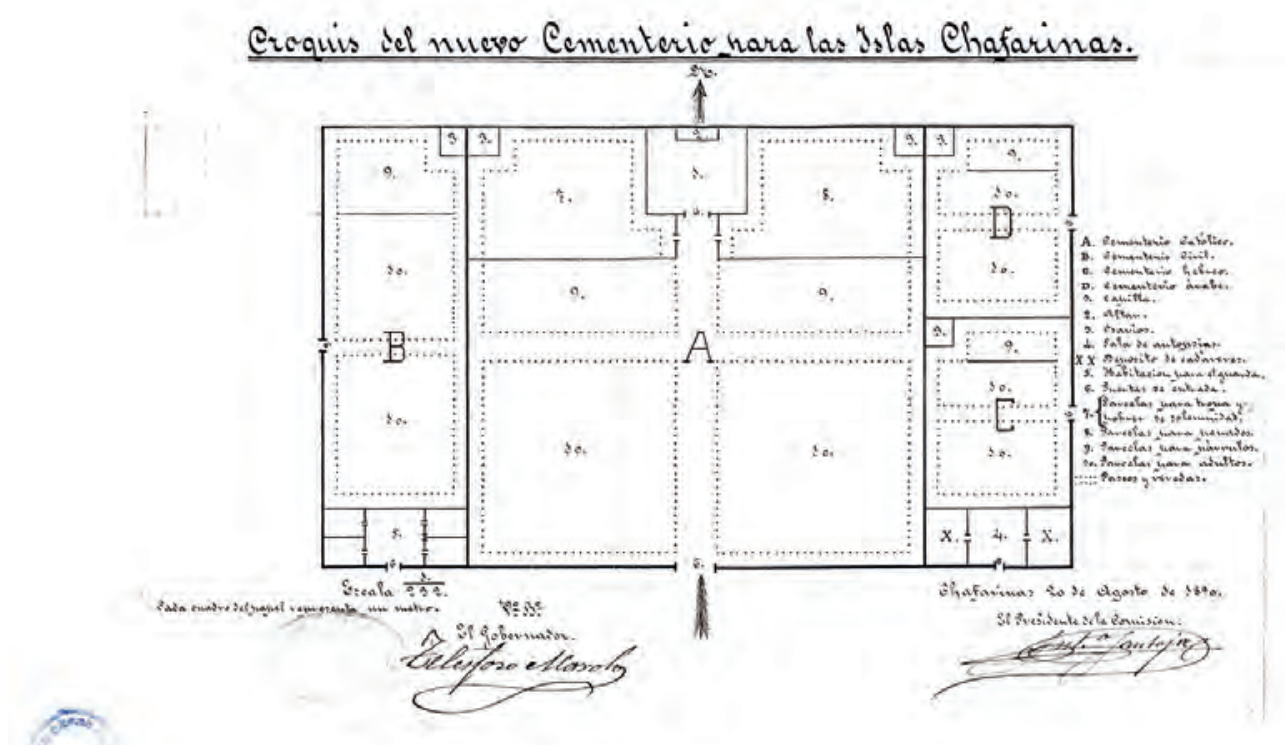

20 de agosto de 1890. Croquis del nuevo cementerio para las islas Chafarinas. AGMS.

En 1890 ya conocemos un proyecto de nuevo cementerio, que debía ser construido en la isla del Rey ${ }^{18}$. Se trata de un espacio más cuidado y que presenta una composición deter minada por espacios $m$ uy diferenciados: cementerio católico (A), civil (B), hebreo (C), árabe (D), y dentro del católico se establecen más divisiones como parcela para tiopa y otra para pobres de solemnidad, parcelas para penados, párvulos y adultos.

La Junta de las islas había propuesto construir el nuevo cementerio en el centro de la isla del Rey, pero la Comandancia de Ingenieros determinó en 1890 que se realizara en el extr emo sur de ésta, donde finalmente fue constr uido, alejado por tanto de cualquier otra actividad que pudiera plantease en el futuro sobre la citada isla.

Posteriormente, y durante un tiempo, la cartografía refleja los dos espacios (como en 1905), el cementerio nuevo y el viejo, hasta que finalmente el viejo deja de señalarse y desaparece todo vestigio de su existencia.

1820 de agosto de 1890, Croquis del nuevo cementerio para las islas Chaf arinas, Segovia, El presidente de la comisión, Antonio Santonja, $\mathrm{V}^{\circ} \mathrm{B}^{\circ}$ el gobernador Telesforo Maroto. AGMS. 


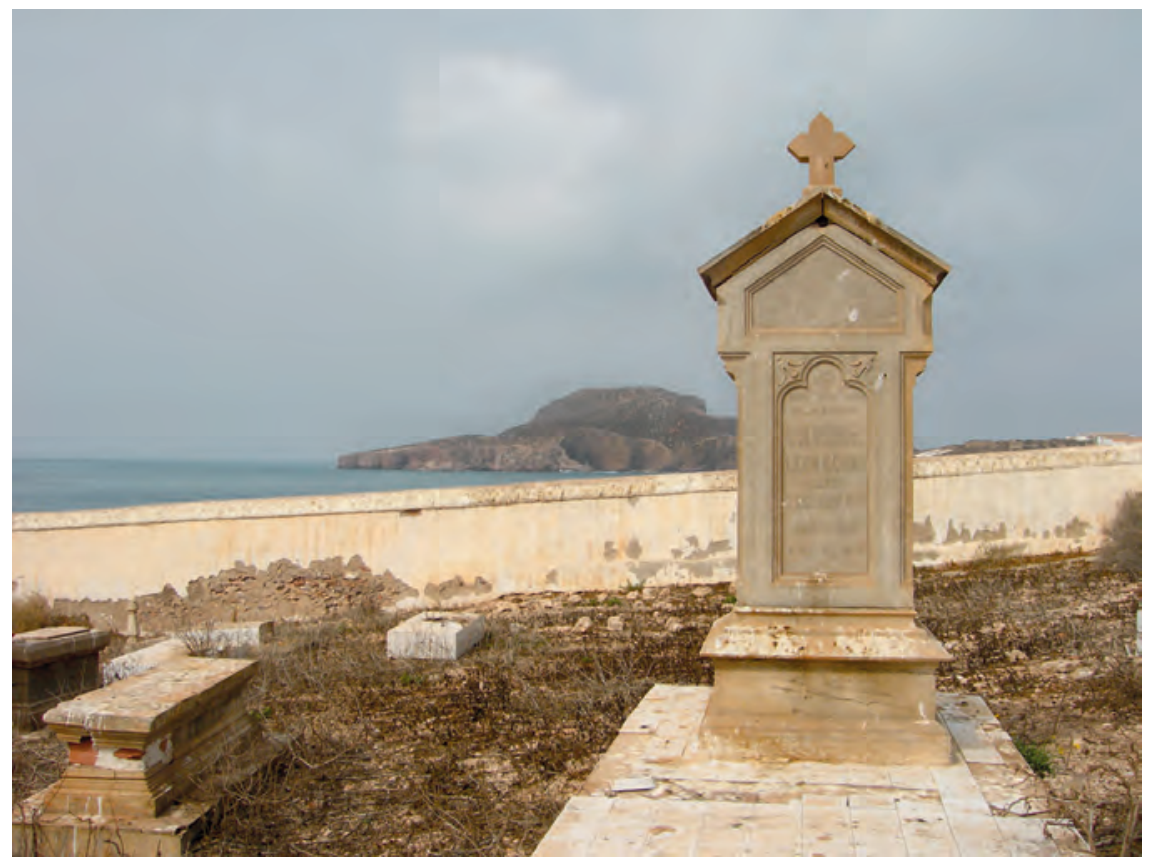

Sector del cementerio, actual.

\section{Referencias históricas de la iglesia}

Construida en un momento en el que se pensaba que las Chaf arinas desempeñarían un importante papel estratégico regional, y que por tanto debía servir a una población numerosa, lo cierto es que las dimensiones del templo y su envergadura siempre estuvieron por encima del exiguo crecimiento demográfico de las islas. Las previsiones no se cumplier on y la iglesia destaca por su monumentalidad y su amplia escala respecto al entorno construido, hecho bien visible desde cualquier aproximación que se realice a la isla de Isabel II,ya que el volumen del templo destaca por encima de cualquier construcción o edificio.

Podemos decir que la iglesia de la Inmaculada Concepción ha sido desde su construcción una gran desconocida en las $\mathrm{r}$ eferencias bibliográficas sobre este archipiélago. Ignorada en los trabajos sobre fortificación y obras militares o civiles, y no estudiada nunca desde el punto de vista de la histor ia del ar te, sólo conservamos breves descripciones de viajeros y escritores que visitaron las islas.

Una de las primeras descripciones nos la da Augusto Jerez Perchet, que visitó las Chafarinas entre 1868 y 1869, y que apuntaba que "su forma exterior es la de un retablo", percibiendo el sometimiento de ésta a un orden arquitectó- 
nico ${ }^{19}$. En 1887, una referencia de la Revista de Geografía Comercial nos indica que por entonces se estaba intentando fundar casas misiones enAlhucemas, Melilla y también en Chafarinas, pero que esto exigía la construcción de edificios para los misioneros, pues en Chafarinas concretamente "el capellán vive de prestado en la habitación del vicario".

En 1893 Rafael Pezzi ${ }^{20}$ escribe escuetamente de ella señalando su"graciosa fachada”. Ese mismo año, Francisco J. de Moya nos aporta el dato que en la isla del Rey "en la parte central de la isla, según proyecto, se piensa establecer un cementerio", con lo que ya señala el traslado del camposanto a la isla más situada al Este y que todavía no se había materializado.

La obra de transformación más antigua de la que nos queda constancia de la iglesia debió producirse entre 1917 y 1920 y afectó a la estética de su fichada, produciéndose en este momento la intervención escultórica de Alberto Sánchez en la fachada y en el Sagrado Corazón que remata el campanario y cuya valoración detallada señalaremos en el apartado siguiente.

En 1920, el ingeniero y escritor Francisco Carcaño ${ }^{21}$ nos dice "la plaza de la iglesia es lo mejor de la isla, es rectangular muy alargada. En el lado menor, al norte, está el templo en cuya fachada de pretensiones arquitectónicas figuran las palabras Domus Dei”. José Antonio Sangroniz ${ }^{22}$ tres años después señalaba que "la iglesia es el mejor edificio del antiguo pr esidio, está muy bien conservada elevándose en la plaza llamada de armas".

Habrá que esperar hasta 1947, para que Rafael Fernández de Castro ${ }^{23}$ aporte algún dato más preciso sobre la iglesia, y así en uno de sus trabajos (uno de los mejores publicados sobre la historia de Chafarinas) relaciona las imágenes de este templo: la Purísima Concepción, Jesús Nazareno, una Dolorosa, San Juan Bautista, la Virgen del Carmen y un Jesús Crucificado.

Pero a finales de los años cuarenta la iglesia estaba en muy mal estado, y a

19 JEREZ PERCHET, Augusto (1873). Impresiones de viaje.Andalucía, El Riff... ; p. 220.

20 PEZZI, Rafael. "Las islas Chafarinas". Memorial de Artillería; p. 282-288.

21 CARCAÑO, Francisco (1920). Las Plazas menores de África: Peñón deVélez, Alhucemas y Chafarinas. Melilla: El Telegrama del Rif.

22 SANGRONIZ, José Antonio (1923). "Las Islas Chafarinas”. Boletín de la Real Sociedad Geográfica, tomo LXIV.

${ }^{23}$ FERNANDEZ DE CASTRO, Rafael. “Acción de España en África. Primer centenario de la ocupación del archipiélago de Chafarinas”. África, n 63-64. 
instancias de Tomás García Figueras (que ocupaba por entonces un alto cargo en la Administración del Protectorado) y del alto comisario Rafael García Valiño, se llevó a cabo una restauración del templo en 1952.

Los autores del proyecto fueron el arquitecto municipal de Melilla, Guillermo García Pascual y el comandante ingeniero Santiago Noreña de la Cámara,actuando como maestro de obras Sánchez Mena. Las obras consistieron en enfoscar todo el exterior y reparar las tejas, consolidando todos sus elementos. Se pintó todo el interior, perdiéndose entonces la pintura anterior con detalles jaspeados y la decoración del enfoscado que marcaba los despieces de sillaes. En este mismo momento, el escultor Francisco Palma Burgos restauró las imágenes de la Purísima Concepción, Nuestra Señora de la Piedad, la Virgen del Carmen, el Nazareno y Jesús en la Cruz. Esta es la única r eferencia que tenemos de una restauración sobre las imágenes de Chafarinas mientras estuvieron en las islas.

Con motivo de la inauguración de las obras se desplazó a las islas un importante número de antiguos $r$ esidentes que celebraron misa en el $r$ emozado templo. En esta ocasión se pr ocesionó a la Virgen del Carmen, aunque en la Semana Santa, la procesión que recorría la isla hasta el final del espigón del puerto, sacaba las imágenes del Nazareno, el Crucificado y la Piedad.

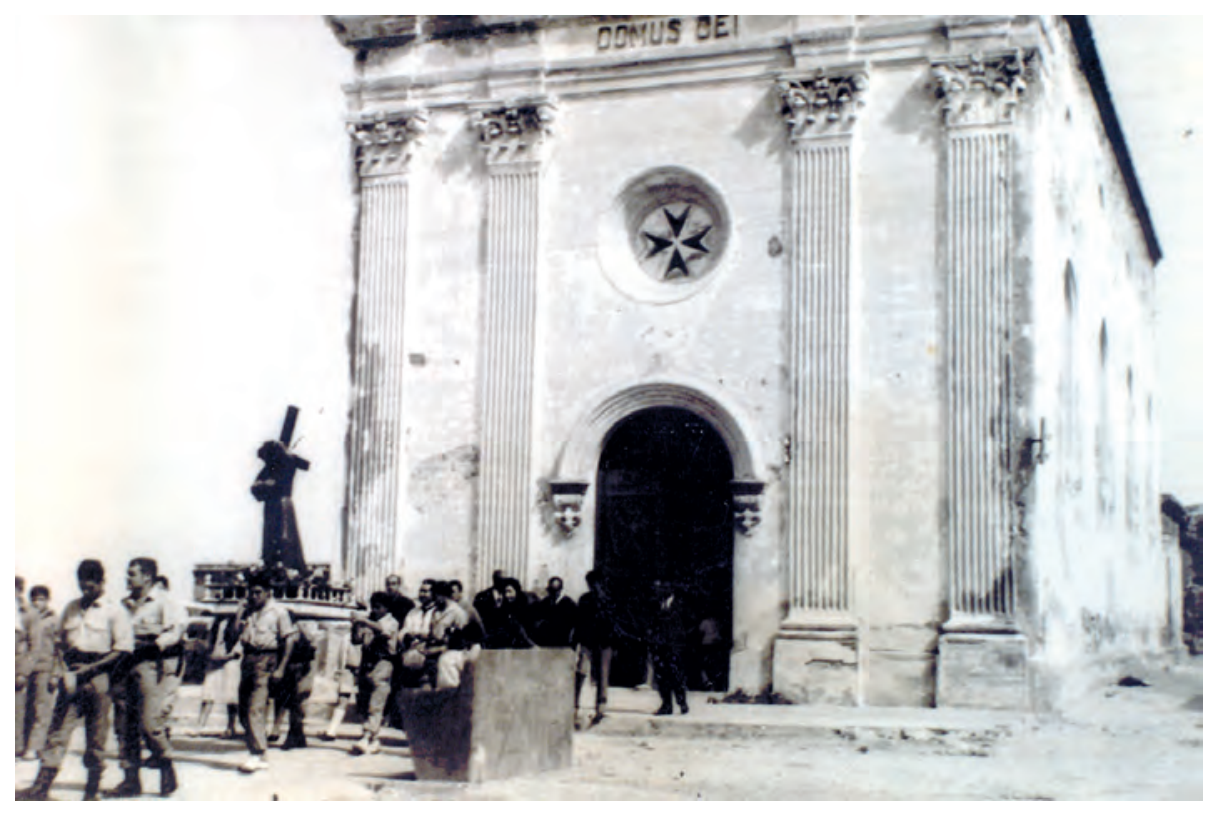

Imagen del Nazareno en procesión delante de la fachada del templo. 


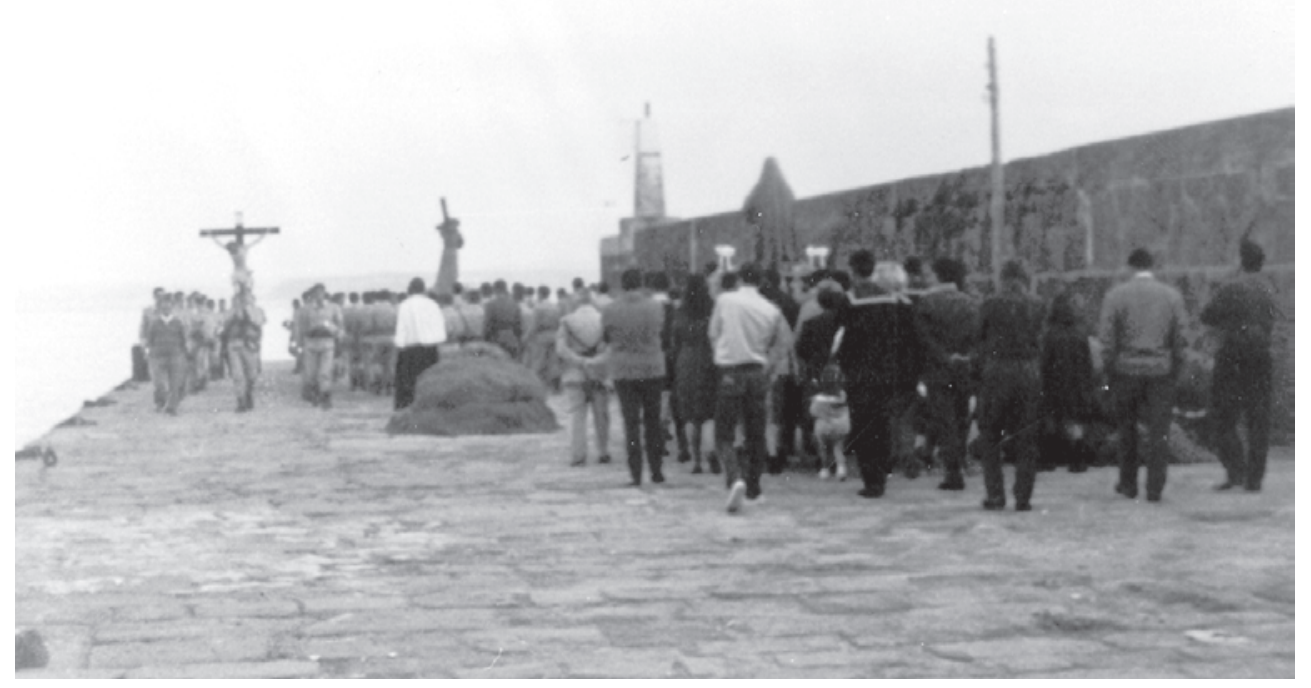

Vista del final del espigón del puerto con la procesión de tres imágenes: la Piedad (de espaldas), el Nazareno y el Crucificado.

La falta de precisión caracteriza la referencia de esta iglesia en el, por otra parte, muy documentado trabajo del in vestigador Moya Casals ${ }^{24}$. En 1954 nos dice del edificio:"reducido y de sencillo gusto arquitectónico, con cuatro figuradas columnas de estilo corintio, ventana circular con la cruz de la orden de Malta y de interior sencillo, dedicado a la Inmaculada Concepción”, descripción que parece demostrar que Moya Casals no estuvo realmente en la isla y que realizaría su descripción a través de fotografías, pues no supo captar la escala del templo.

Posteriormente, José Luis Blasco ${ }^{25}$ se ocuparía de esta iglesia en un interesante artículo en el que apor ta nuevos datos: señala que el templo fue construido en 1862, destaca por v ez primera el valor del retablo barroco, al que compara con el retablo del Rosario de Melilla adjudicándole la misma fec ha y traza, y describe las campanas. También nos señala que el archivo parroquial de este templo se encontraba en la iglesia del Sagrado Corazón de Melilla.

\footnotetext{
24 MOYA CASALS, Enrique (1954). Melilla piadosa y tradicional, 1954; p. 110-111.

25 BLASCO LÓPEZ, José Luis (1992). "Iglesias de laVicaría de Africa. Las Islas Chafarinas. La iglesia de la Inmaculada Concepción de las Chafarinas” El Telegrama de Melilla, 11 de octubre de 1992; p. 10 y 11.
} 
Como resumen de todas estas referencias, diremos que realmente la iglesia de la Inmaculada Concepción de las Chaf arinas es una obra arquitectónica muy desconocida en la bibliografía española y que las referencias sobre ella casi siempre han pecado de ser muy escuetas y poco analíticas.

\section{Una obra del escultor vanguardista Alberto Sánchez en Chafarinas}

Todavía hoy día es un hecho el desconocimiento que en nuestro país se tiene sobre la figura y la obra de uno de los atistas clave en el mundo de la escultura y de la vanguardia española del siglo XX: Alberto Sánchez, pero aún lo es más que una de sus primeras obras la realizara en Chafarinas y en concreto en su iglesia.

Este autor, conocido como Alberto, nació en Toledo en 1895, muriendo en Moscú en 1962. Durante sus primeros años de vida desempeñó varios trabajos humildes hasta que en 1916, cuando cumplía 21 años entró en la Caja de Reclutamiento y al año siguiente se incor pora al servicio militar en la zona de Melilla. Estuvo destinado en el Regimiento Mixto de Ingenieros de Melilla durante 3 años, recibiendo la instr ucción en esta ciudad, aunque el $r$ esto de su servicio lo desarrolló por toda la zona oriental de Marruecos. Estuvo destinado en la zona del K ert, Asset, Kandusi, Cabo del Agua y en las islas Chaf arinas, lugares donde realizó sus primeras obras conocidas.

En 1920 abandona Melilla y regresa a Madrid iniciándose desde entonces en las nuevas tendencias artísticas que le ligarán a la vanguardia española. En 1925 participó en la Exposición de Artistas Ibéricos en el Retiro de Madrid y participó en 1937, junto a Picasso y Miró,en el Pabellón de España de la Exposición Intemacional de París, donde realizó la escultura «El Pueblo español tiene un camino que conduce a una estrella». El transcurso de la contienda motivó su exilio definitiv o del país y en 1938 se instaló en Moscú, ciudad donde proseguiría su obra hasta su fallecimiento. Esta accidentada biografía determina actualmente que la producción artística anterior a 1938 se haya perdido en su mayor parte, sobre todo debido al bombardeo que sufrió su estudio madrileño, por lo que resulta del máximo interés la documentación de su obra durante este periodo.

Conocimos las primeras referencias del trabajo de Alberto Sánchez en Melilla gracias al catálogo de su obra pub licado en $1981^{26}$, donde el pr ofesor

26 Alberto, esculturas, óleos, dibujos, bocetos y fotografías. Universidad de Málaga, Museo de Málaga, enero febrero de $1981 ; 55 \mathrm{p}$. 
Isidoro Coloma recogía parte de las anotaciones biográficas aportadas sobre Alberto por Luis Lacasa en 1960. Así sabemos que en Melilla «hace sus pr imeras esculturas: una cabeza de mor o y otra de mora, talladas en piedra caliza; toma apuntes y realiza dibujos del natural. Modela un Corazón de J esús, concebido por planos, para la fachada de una iglesia en la isla Chaf arinas. En el Cabo de Aguas realiza un escudo de España inventado, con cabezas de moros, el Castillo de Ingenieros, etc. Modela figuras de rifeños que vacía en yeso».

Durante este per iodo en el que pasa largos per iodos de tiempo al air e libre se dedicó a "soñar y leer" por lo que Alberto "recordó siempre con nostalgia” esta estancia en Melilla y Chafarinas ${ }^{27}$.

En principio, la búsqueda de la obra de Alberto Sánchez en Melilla ha resultado parca en resultados. Sobre la referencia de su obra en Cabo del Agua (actual Ras-el-Ma), pequeña población del oriente marroquí situada frente a las Islas Chafarinas, diremos que el trabajo de campo efectuado no permite en absoluto adivinar donde pudo estar situado el edificio en el que constriría el escudo original de España rodeado con cabezas de moros. Este edificio estuvo localizado en el antiguo campamento militar que estaba sobr e una pequeña meseta que dominaba el embarcadero y de cuya huella no queda actualmente rastro alguno.

La referencia de la obra realizada en las islas Chafarinas es sin embargo la que ha ofrecido resultados más concretos. Efectivamente en la parte superior de la fachada de la iglesia, sobre el campanario, existe actualmente un tondo en el que destaca una escultura del Sag rado Corazón de J esús. En un pr incipio las posibilidades de que ésta fuera la escultura ejecutada por Alberto parecían bastante concluyentes, pero aún intentamos clarificar más este asunto.

Intentamos documentar que la escultura del Sagado Corazón hubiera sido ejecutada al mismo tiempo que la iglesia, a mediados del XIX, por lo que no sería obra de Alberto. Esta posibilidad sin embargo la descartamos totalmente gracias a dos documentos. El primero es un alzado de la fichada que aún sin estar fechado podemos situar hacia 1862 . El segundo es un grabado de la iglesia publicado en 1893 por la revista La Ilustración Española y Americana, donde podemos observar como por entonces la iglesia no contaba con escultura alguna en su fachada. Por su parte, también consultamos una fotografía del mismo templo, fechada en 1921, donde sí aparece ya el Sagrado Corazón, por lo que deducimos que éste

27 MARTIN, Peter (1971). Litoral, no 17-18, Homenaje al escultor Alberto Sánchez. 
fue realizado entre 1902, donde se apr ecia que en la par te alta, en el lugar del frontón, se había colocado un reloj. También contamos con la fotografía de 1921, donde sí apar ece ya el Sagrado Corazón, por lo que deducimos que éste fue realizado entre 1902 y 1921 . Esta cronología encaja con el per iodo en el que Alberto Sánchez estuvo destinado en la zona (1917-1920).Todos estos datos apuntaban con mucha insistencia a su autoría per o una minuciosa encuesta lle vada a cabo entre antiguos vecinos de las islas, nos deparó nuevos datos. Efectivamente el Sagrado Corazón que coronaba la fachada de la iglesia fue una de las primera obras de Alberto y es el que aparece en la foto de 1921,pero en las obras de restauración llevadas a cabo en 1952, y debido a su mal estado de conservación (en parte por la endeblez de los materiales con los que fue esculpido),se realizó una nueva escultura que sustituyó a la anterior. De esta manera se perdía una de las pimeras obras de uno de los más importantes artistas de nuestra vanguardia y que hubiera figurado con derecho propio como una joya en cualquier museo español.

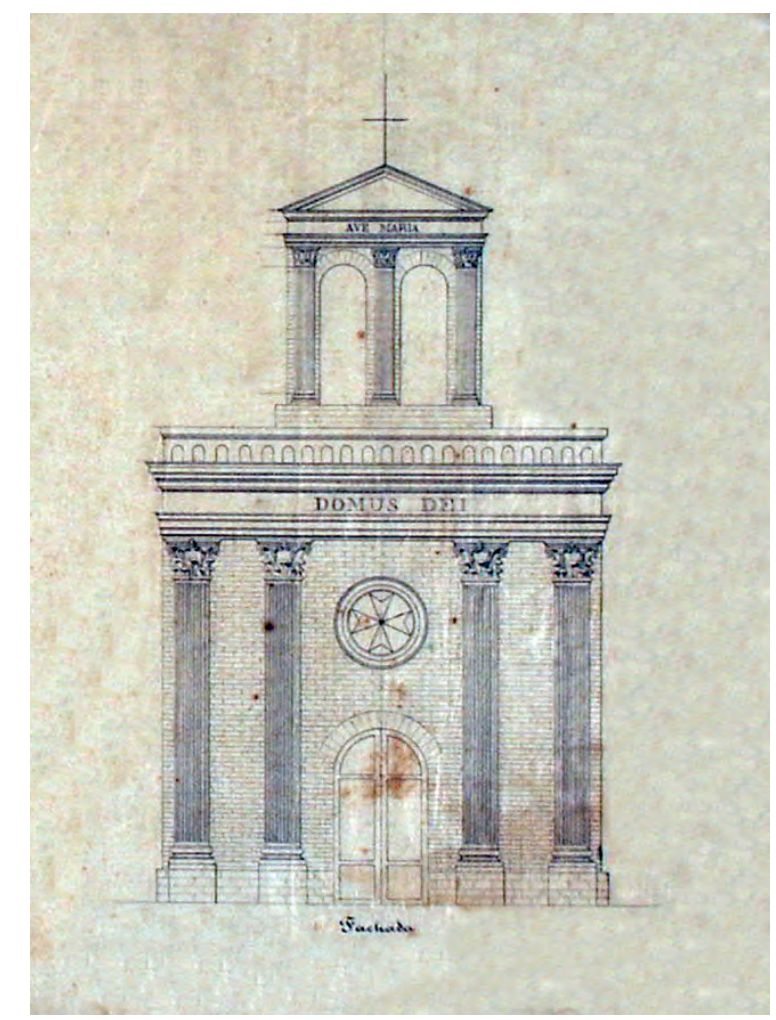

Fachada de la iglesia: proyecto (hacia 1862). IHCM. Melilla. 
Sin embargo la intervención de Alberto Sánchez no se centró exclusivamente en el Sagrado Corazón, ejecutando también la transfor mación de la archivolta de la entrada principa, junto con las dos ménsulas que la soportan. Estas ménsulas representan a dos angelotes alados, y se con vierten posiblemente en la pr imera obra conocida del escultor. Estas esculturas revisten un gran valor histórico al ser la primera obra conservada en la actualidad de este español universal.

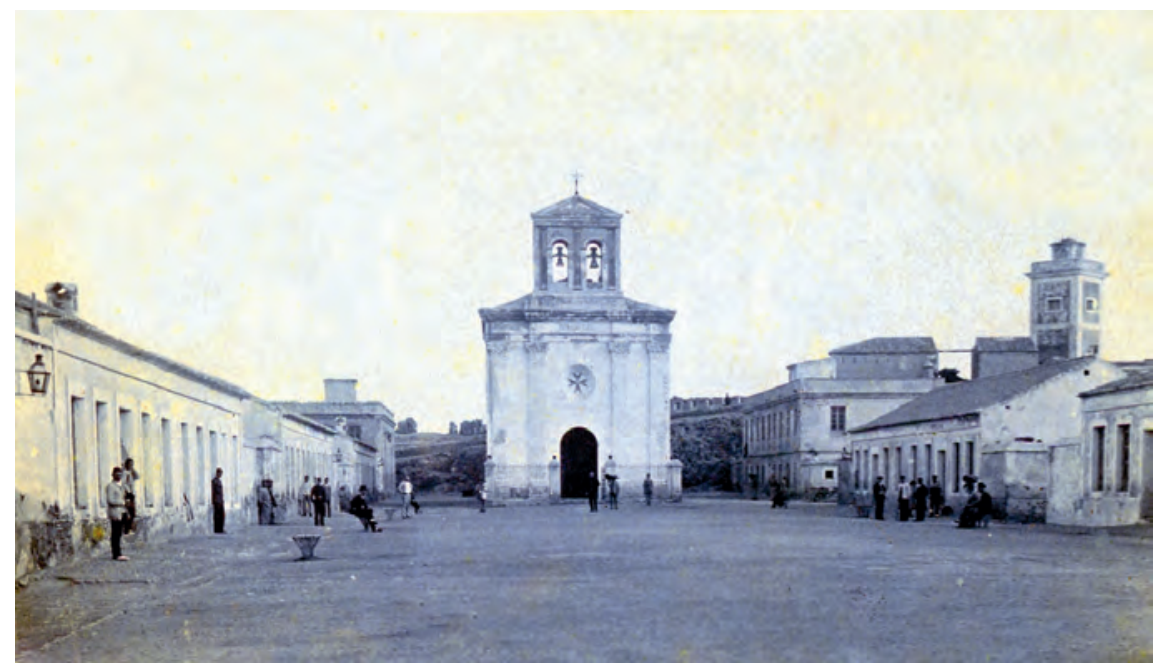

Plaza de la iglesia a finales del siglo XIX, mantiene el frontón original.FCOML.

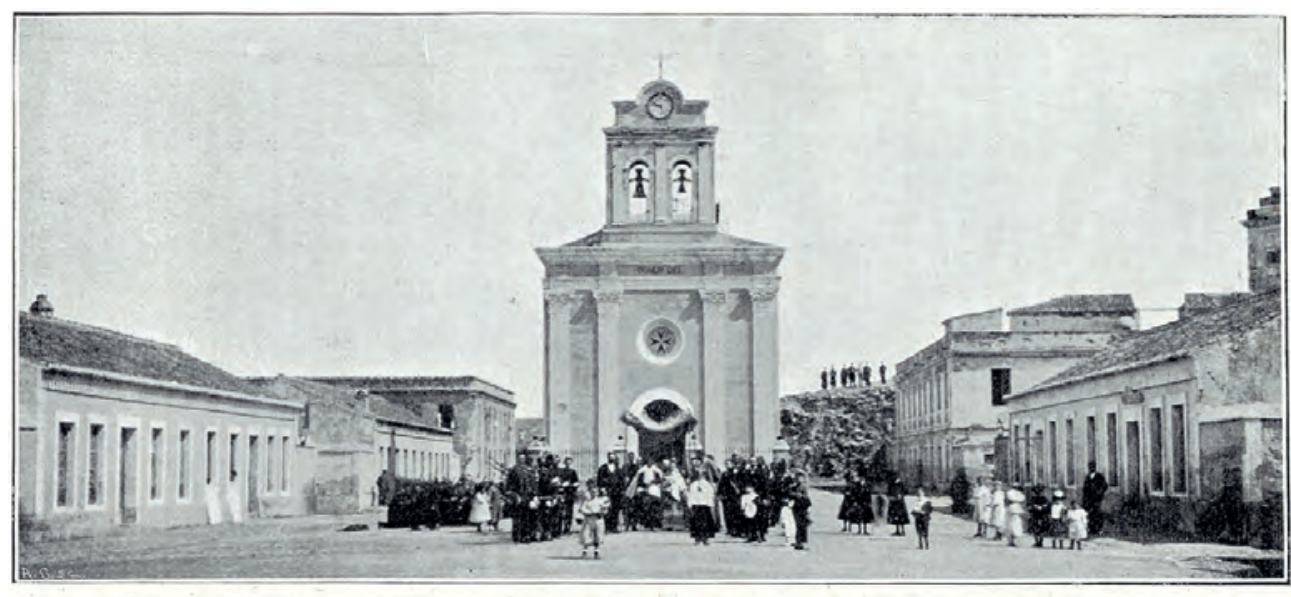

PLAZA DE LA IGLESIA.

En 1902 el remate superior ya se había transformado y en su interior circular hay un reloj. La Ilustración Española y Americana, 15 de noviembre de 1902. FCOML. 


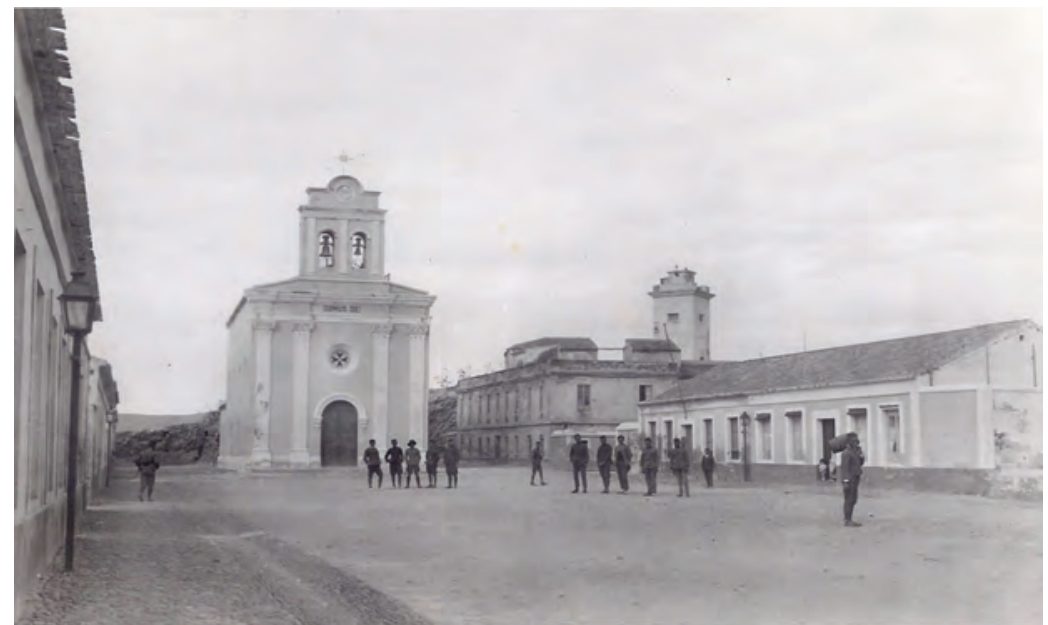

Fotografía de la iglesia hacia 1921, en la que ya se aprecia la escultura y la arquivolta sobre la puerta.

En junio de 2001,y con motivo de una magna exposición deAlberto Sánchez en el Museo Reina Sofía de Madird, el hijo del escultor Alcaén Sánchez, aún desconocía el paradero de esta escultura, declarando que pedía "conocer el destino de una obra monumental, un Sagrado Corazón que fue instalado en la iglesia de las islas Chafarinas, ahora controladas por el Ministerio de Defensa" ${ }^{28}$. Si bien no es la original, el relieve actual sí nos recuerda el paso de este artista por las islas Chafarinas, periodo que fue de formación y de aprendizaje de este gran creador.

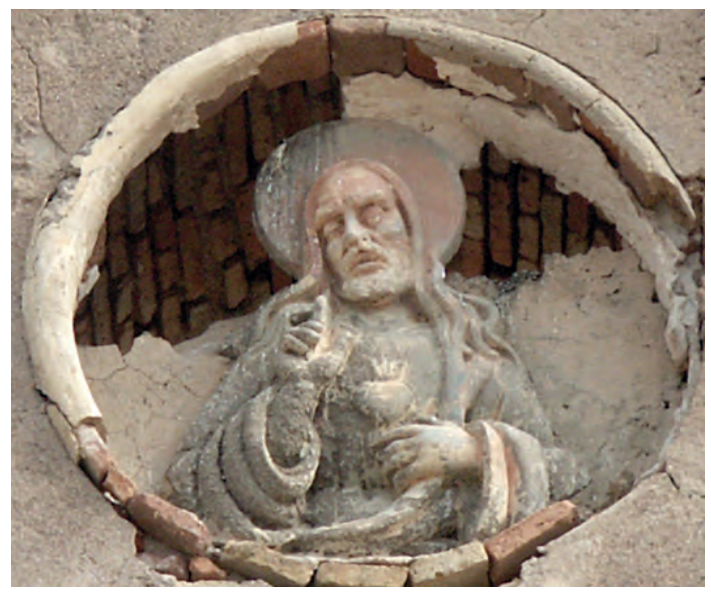

Tondo: Sagrado Corazón de la iglesia. Fotografía ABN.

28 El País, 27 de junio de 2001; p. 39. 


\section{Descripción del templo. El exterior}

A pesar de que en 1848, el mismo día de la llegada de las fuerzas españolas, el sacerdote Bartolomé de Fuentes puso a las islas bajo la advocación de la Adoración de los Reyes Magos, la iglesia está dedicada a la Inmaculada Concepción.

Este templo está situado en la zona más alta de la isla, en una amplia explanación que forma lo que puede considerarse la plaza mayor de la isla Isabel II. Se trata de un espacio urbano de planta r ectangular muy alargada, de unos 40 por 100 metros, que permite una buena visualidad y perspectiva sobre la iglesia.

La formación histórica de este espacio pr ocede de la idea de cr ear una población ordenada, en la que los edificios militar es asumieran una trama que formara la plaza de armas principal.

El templo, de una sola na ve, presenta una amplia planta r ectangular de 11 metros de fachada y 22,5 metros de lado, que hacen una superficie de planta de casi 250 metros cuadrados. En la cabecera se sitúan dos habitaciones de menor altura que el resto del templo y con muros más estrechos, que son utilizadas como sacisstía y cuyas medidas son 11 por 7,30 metr os, lo que da una superficie de 80 metr os cuadrados. Por ello se puede asimilar este templo a las típicas iglesias denominadas “de cajón”, tipología muy común en toda la Edad Moderna.

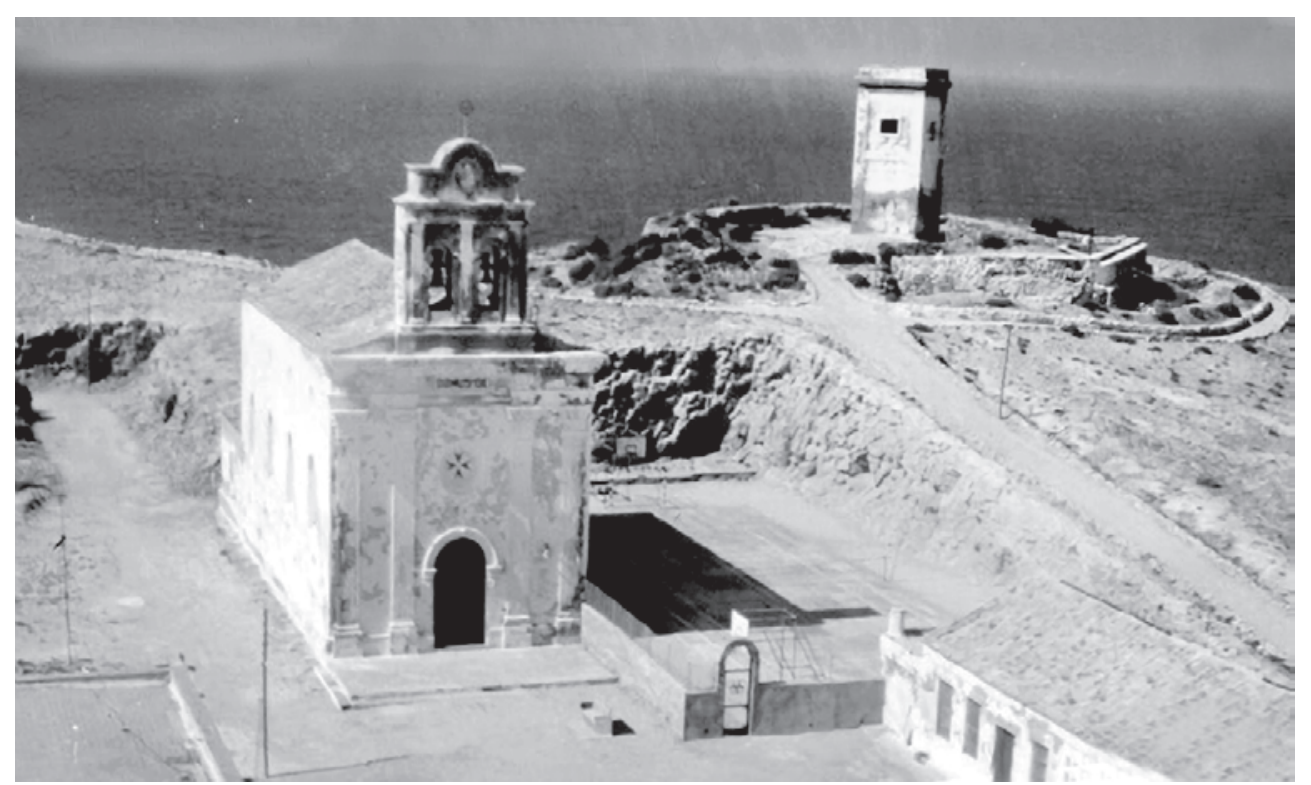

Fotografía de la iglesia y la batería de la Conquista, hacia 1940. 


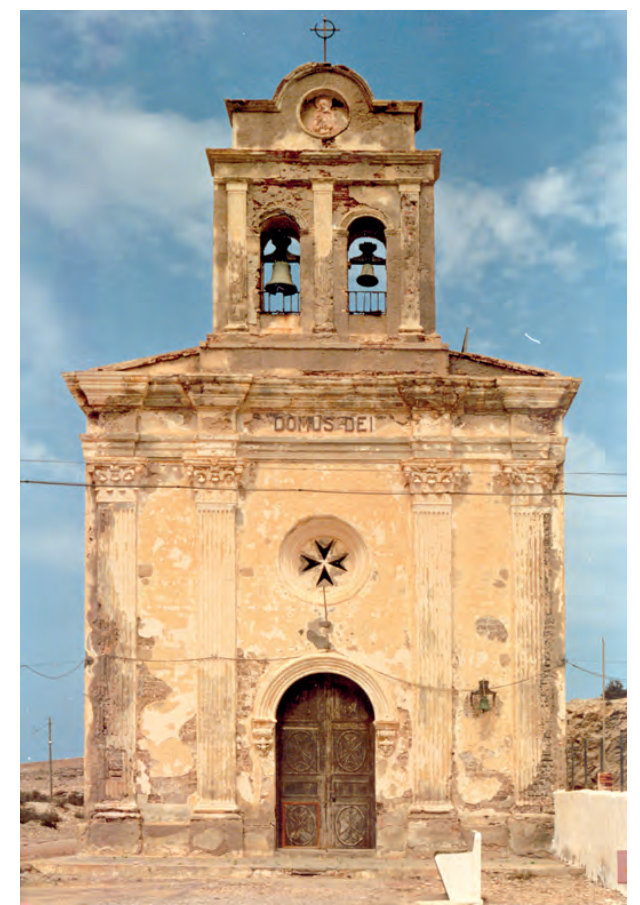

Fachada de la iglesia, en 1987, en la que todavía estaban colocadas las campanas. Fotografía ABN.

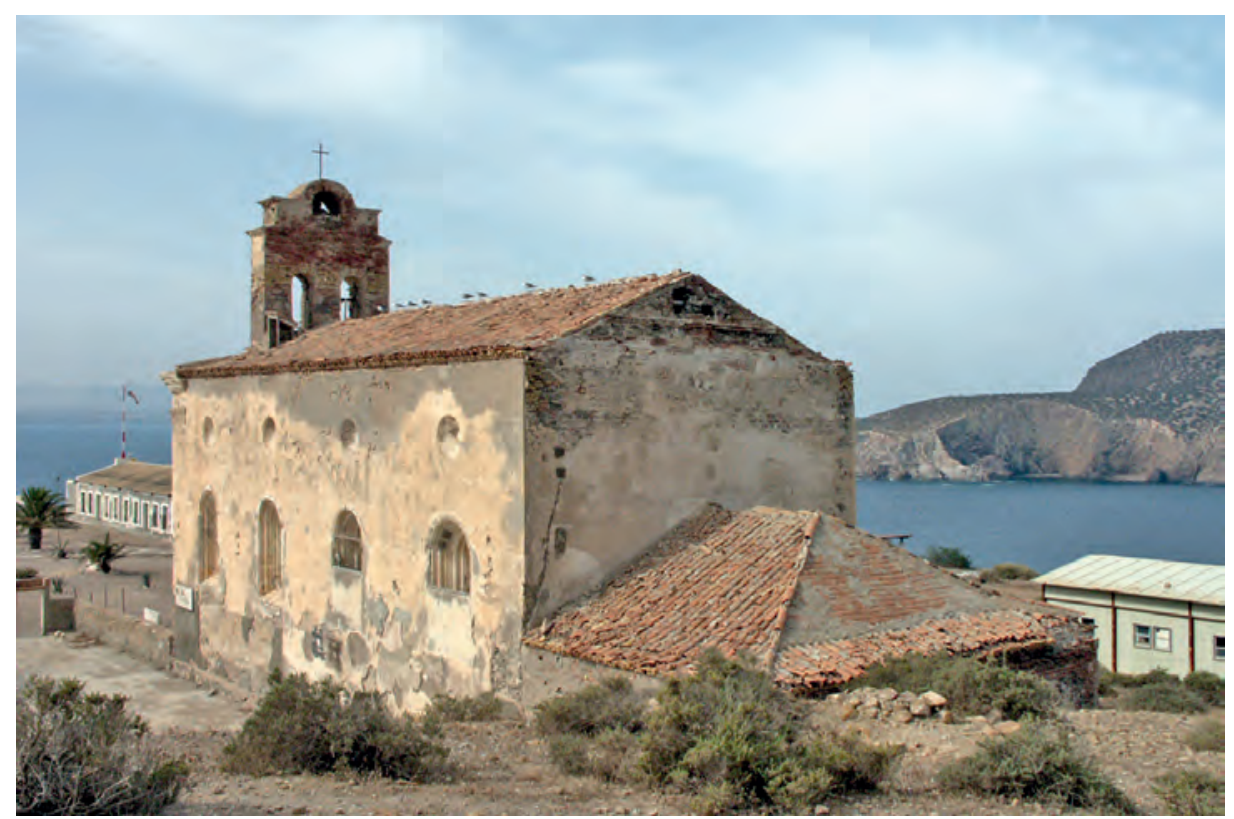

Vista lateral y sacristía, 2005. Fotografía ABN. 


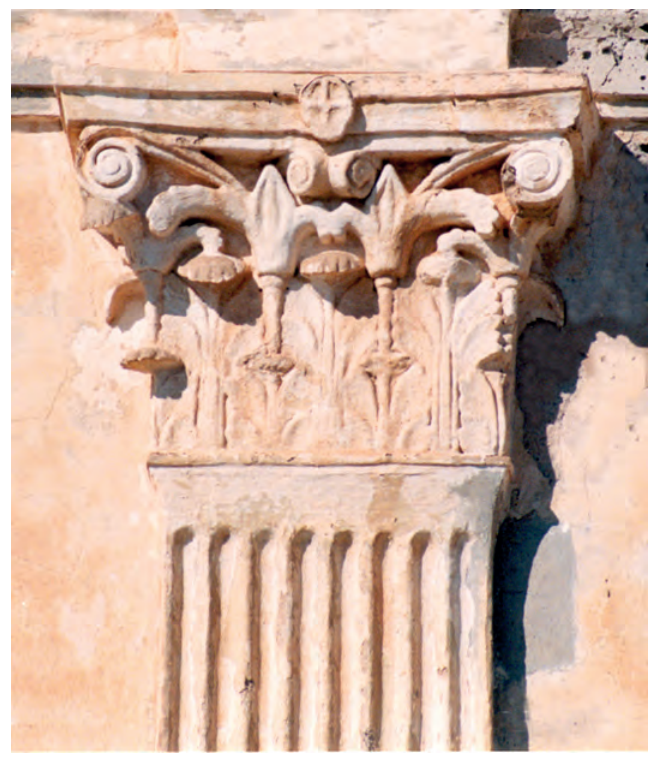

Capitel de la fachada, 2005. Fotografía ABN.

La fachada, de 11 metros de lado, presenta un orden gigante de 4 pilastras adosadas con fuste acanalado a bisel de 8 estrías . Las pilastras se asientan sobre basa y podium, y rematan en sendos capiteles compuestos,con cuerpo corintio y róleos de volutas en su remate.

Las cuatro pilastras se ordenan dos a dos, centrando la puerta principal con arco de medio punto y arquiıltas en su intradós. El arranque de este arco se apga sobre dos ménsulas que a su v ez se asientan sobr e dos esculturas adosadas que representan cabezas de querubines alados. Sobre esta entrada se sitúa un r osetón circular también abocinado con arquivoltas y en su centro la cruz de Malta calada. Esta cruz de Malta vuelve a repetirse en los cuatro cuarteles de la puerta exterior.

Sobre las cuatro pilastras de orden gigante se eleva el entablamento formado por una comisa, un friso liso en el que se pueden leer las palabras DOMUS DEI (MORADA DE DIOS), y otra cor nisa de remate más voluminosa que la anterior. Es de destacar el juego de v olúmenes de este entablamento, pues las pilastras se prolongan formando entrantes y salientes en las comisas, lo que dota al conjunto de una gran plasticidad y movimiento barrocos.

Finalmente, se inicia un leve arranque de tímpano, que se interrumpe bruscamente al aparecer el cuerpo del campanario centrado en la fachada. Este campanario presenta dos vanos con arco de medio punto entre tres pilastras acanala- 
das de capitel simple que soportaba dos campanas actualmente desmontadas. El campanario aparece rematado por cornisa y sobre ella un cuer po añadido de perfil curvo que incluye un tondo con el relieve del Sagrado Corazón -que fue obra de Alberto Sánchez-, y finalmente una cruz de hierro.

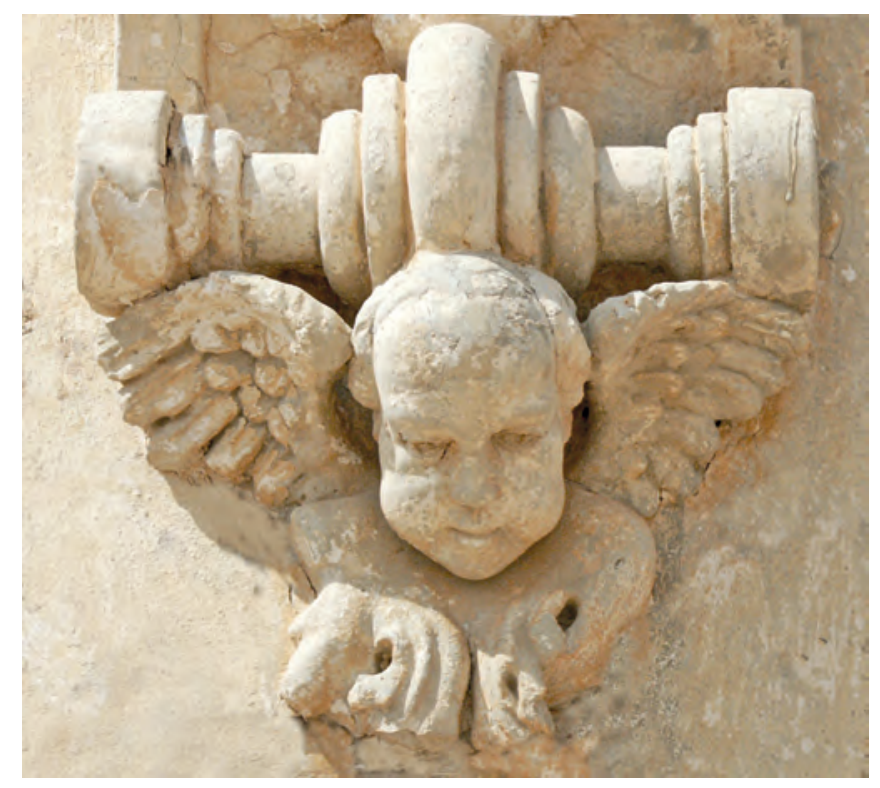

Querubín de la fachada, 2003, obra de Alberto Sánchez. Fotografía ABN.

Según imágenes antiguas, la iglesia presentaba el atrio circundado por una balaustrada, hoy desaparecida. La fachada no ha debido sufrir demasiadas intervenciones, salvo la que transforma el tímpano del campanario en el cuerpo curvo que hoy día podemos ver con el tondo escultórico. En cuanto al color y enfoscado, en las fotos antiguas se percibe una diferencia de color entre el paramento de la fachada y los elementos en resalte como pilastras y comisas: Esta diferencia de color se apr ecia perfectamente en la r estauración de 1952, aunque actualmente se halla perdido.

Por lo que respecta a las fachadas laterales, de 22,60 metros, son simétricas y presentan una mayor sencillez y simplificación con respecto a la principal, no prolongándose el juego de cor nisas y entablamento en éstas. Cada una presenta cuatro ventanas muy alargadas, casi como amplias saeteras de raigambr e románica, que forman arcos de medio punto que en su abocinamiento determinan arquivoltas. Estas ventanas tuvieron cristaleras de color en su momento. 


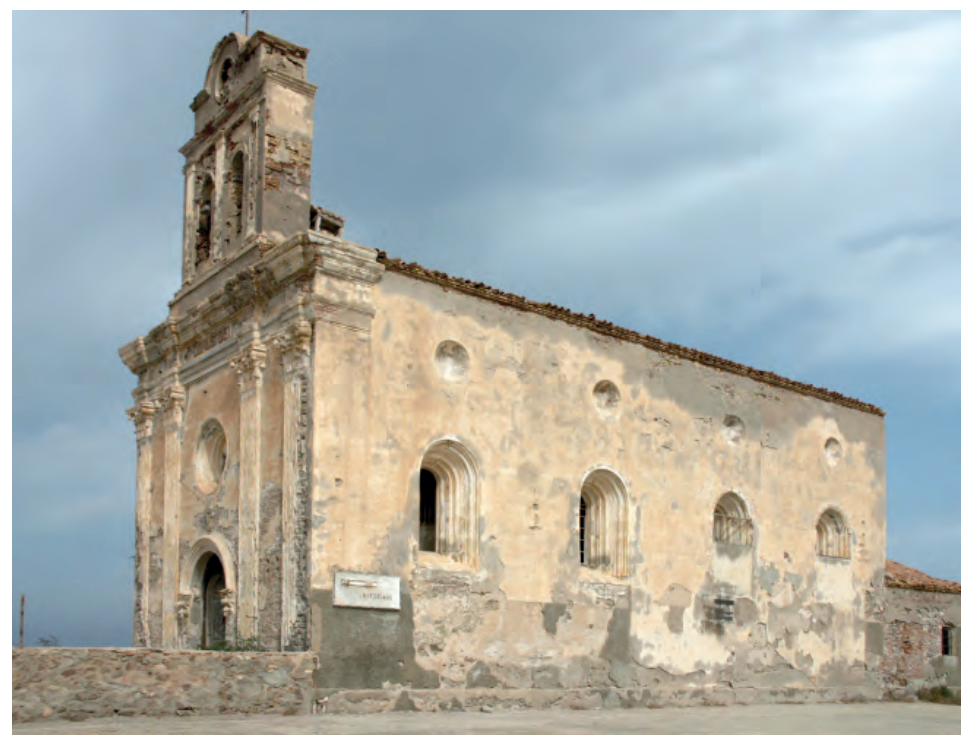

Fachada y nave lateral, 2005. Fotografía ABN.

Sobre estas ventanas se sitúan sendas aber turas circulares de perfil también abocinado, actualmente cegadas (al menos desde 1952), que coincidirían con la parte alta de la falsa bóveda del interior, con probabilidad para facilitar su ventilación. Por último en la cabecera se sitúa la sacristía, como edificio adosado de menor altura y dimensiones que el cuerpo principal del templo.

Actualmente la fachada que se encuentra en peor estado cor responde al lado del Evangelio en la calle de SanAntonio, así como la cabecera, al estar más sometidas al viento del Norte y más desprotegidas, estando la del lado de la Epístola,calle de la Iglesia, más resguardada.

La sacristía tiene su entrada exterior por esta calle de la Iglesia. Este edificio adosado a la Iglesia por su cabecera, tiene mucha menor altura que el cuerpo principal del templo, y está rematado por un cuerpo de teja sobre armadura de madera.

Junto al campanario, sobre la cubierta, se observan unas escaleras que permitían la subida a este lugar desde el inter ior del templo. De las dos campanas que tenía la iglesia, la mayor estaba colocada a la derecha y la menor en la parte izquierda. La primera de ellas tenía la siguiente inscripción: "Señor San José, ora pro nobis. 1885. La hizo D. Manuel Rivas". Y la segunda: "San Juan Bautista. Ferrería de Herrería. 1863. Siendo subdelegado Castrense y Canónigo de la Santa Iglesia Catedral de Málaga el Sr D. Enrique Crooke". La campana pequeña fue 
la primera que se bajó del campanario y junto a la mayor fueron llevadas a Madrid. Como ambas estaban en muy mal estado, las volvieron a fundir reproduciendo sus primitivas inscripciones, a las que añadieron "Santa María de la Dehesa. 1995" nombre de la iglesia castr ense en las que las instalar on y año en que volvieron a sonar estas campanas de Chafarinas en Madrid.

\section{Estudio del interior de la iglesia}

Dentro del templo, tras atravesar la puerta exterior, nos encontramos un pequeño atrio o antesala del cuepo principal del edificio. Desde este atrio, accedemos a la nave principal y única mediante una gran puerta rectangular de dos hojas. Esta puerta presenta una tracería interesante donde se repiten las cruces de Malta con otros motivos geométricos.
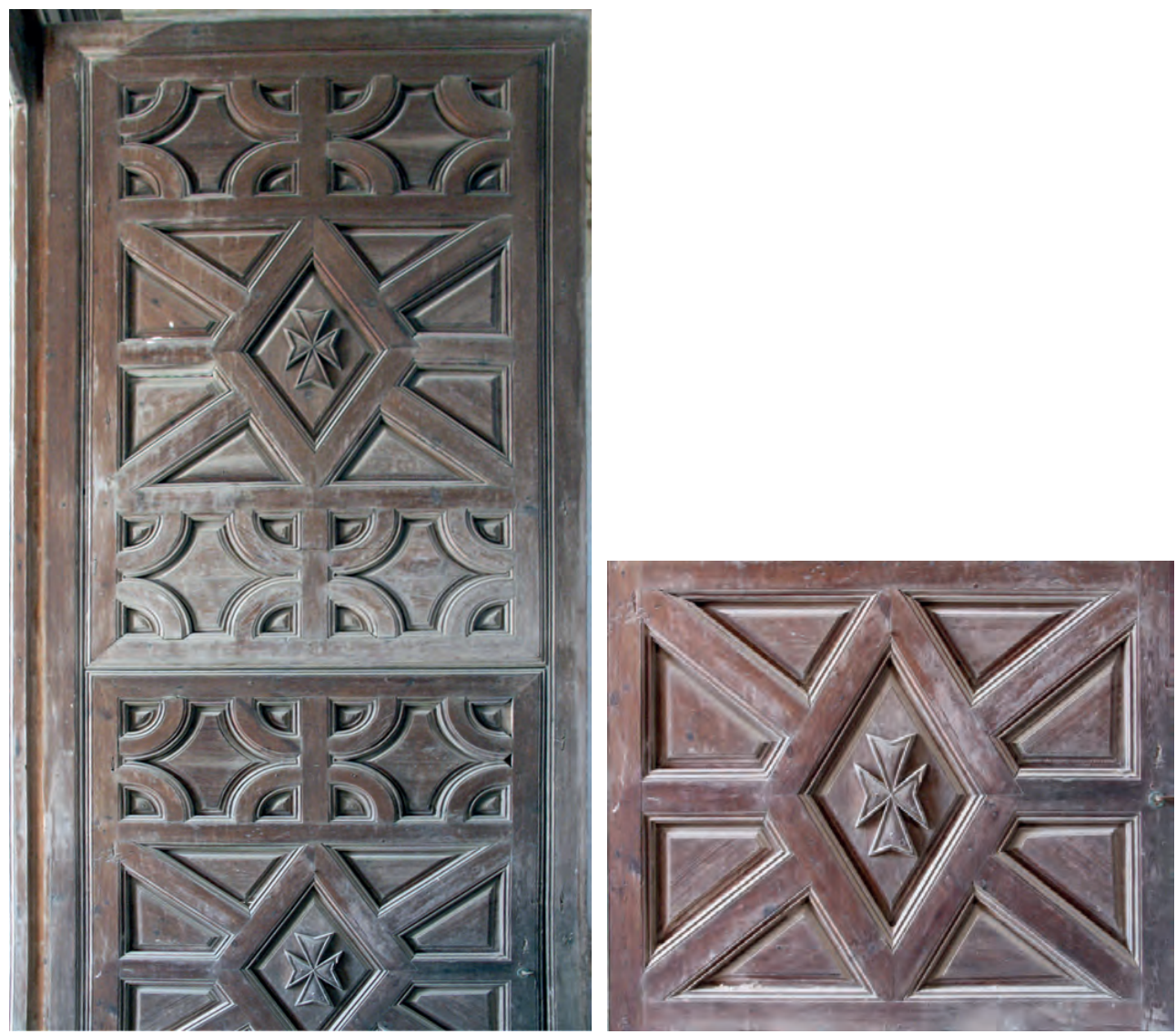

Puerta y detalle, 2004. Fotografía ABN. 
En esta zona de los pies del templo se sitúan, a derecha e izquierda de la entrada, dos habitaciones, la del Evangelio es el Baptisterio que contaba con pila bautismal de mármol ya desaparecida y la de la der echa alberga la subida por escalera de caracol al mismo coro . El coro, muy luminoso debido al $r$ osetón calado con la cruz de Malta y ventanas laterales, cuenta con una balaustrada de madera, arrancando de él otra escalera de caracol que conduce hasta el campanario. Se trata de un espacio pr ivilegiado por la luminosidad y las per spectivas sobre la iglesia, que tiene 23 metros cuadrados.

La iglesia es de nare única y planta rectangular de unos 250 metos cuadrados, lo que unido a la ele vación de su alzado pr oporciona un amplio espacio arquitectónico.

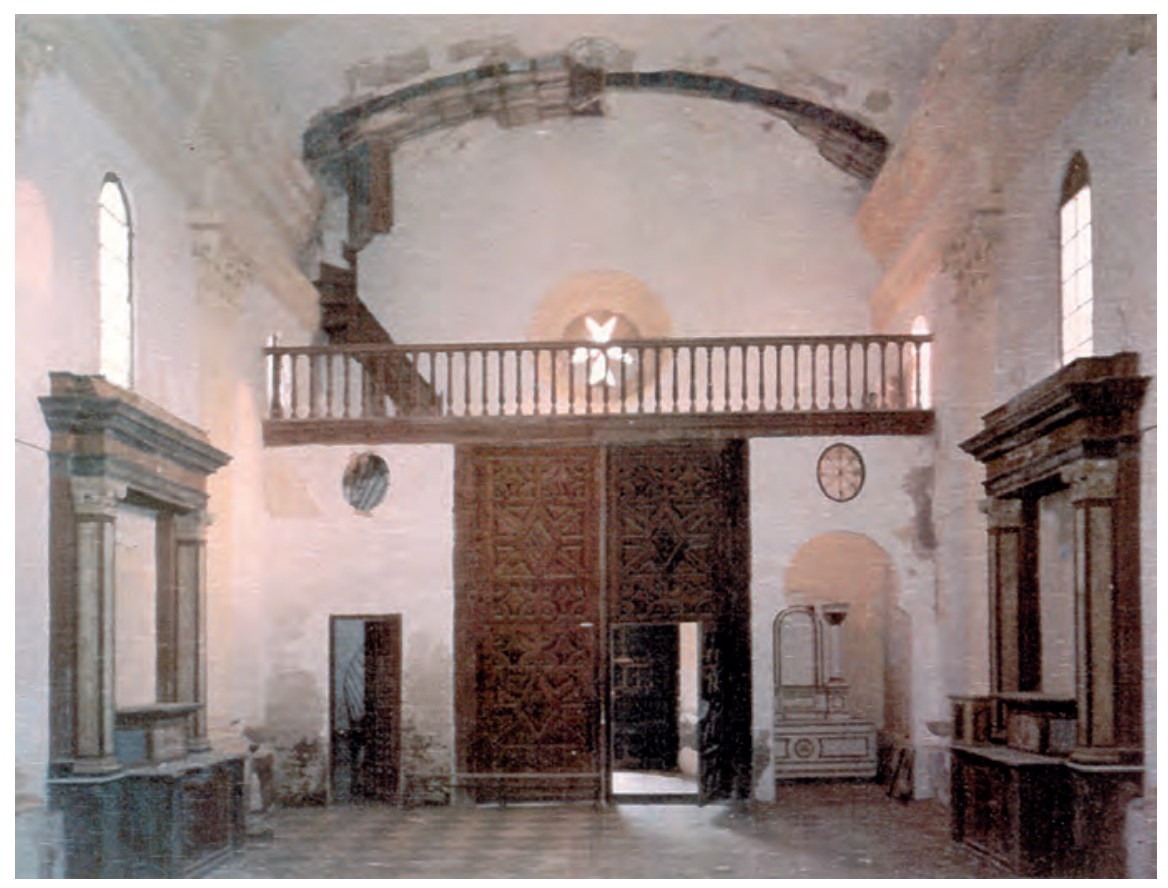

Vista del interior. Coro y capillas. Hacia 1992. Fotografía ABN.

La estructura de la cubier ta está construida de cerchas de madera a dos aguas, de la que pende una falsa bóreda rebajada con falsos arcos fajones sobre la prolongación de las pilastras (tres por cada lado) y tres florones de escayola en la clave y entre los fajones. Toda esta parte se encuentra actualmente muy deteriorada, debido a su carácter añadido y espurio. 


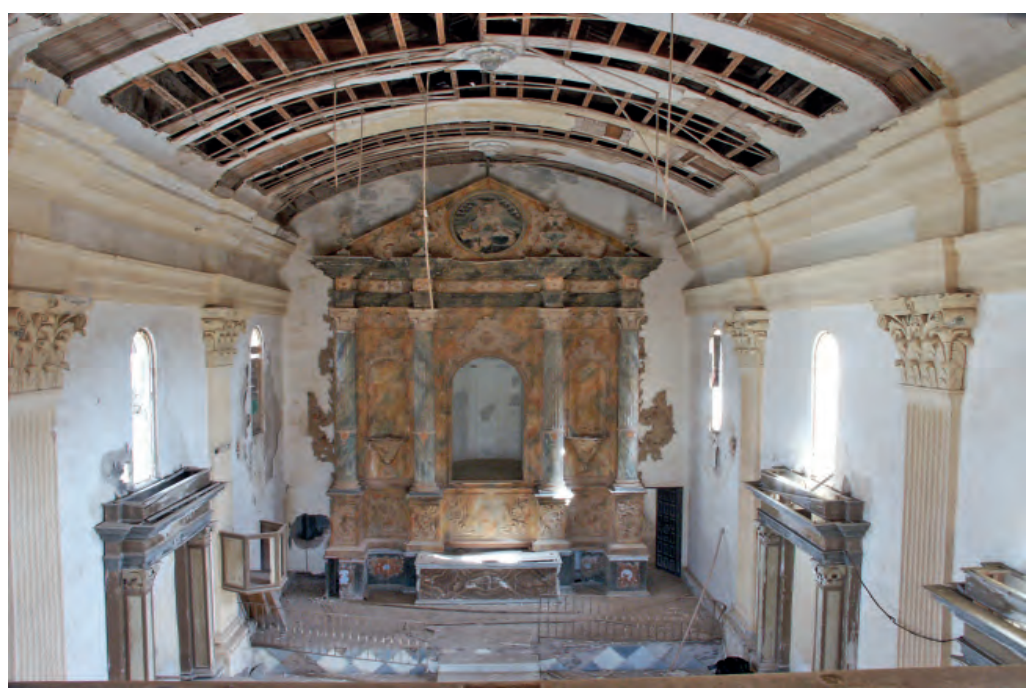

Vista de la cabecera, 2005. Fotografía ABN.

Los muros interiores están enfoscados, al ser los materiales de construcción de poca vistosidad. La decoración es simétrica en el lado de la epístola y del evangelio, y presenta $4 \mathrm{v}$ entanas entre tres pilastras adosadas de capitel compuesto corintio con volutas y fuste acanalado ( 8 acanaladuras) de traza similar a las que se sitúan en la $\mathrm{f}$ achada. Presenta también idéntico entab lamento cuya parte final sirve de apoyo al arranque de la falsa bóveda de escayola.

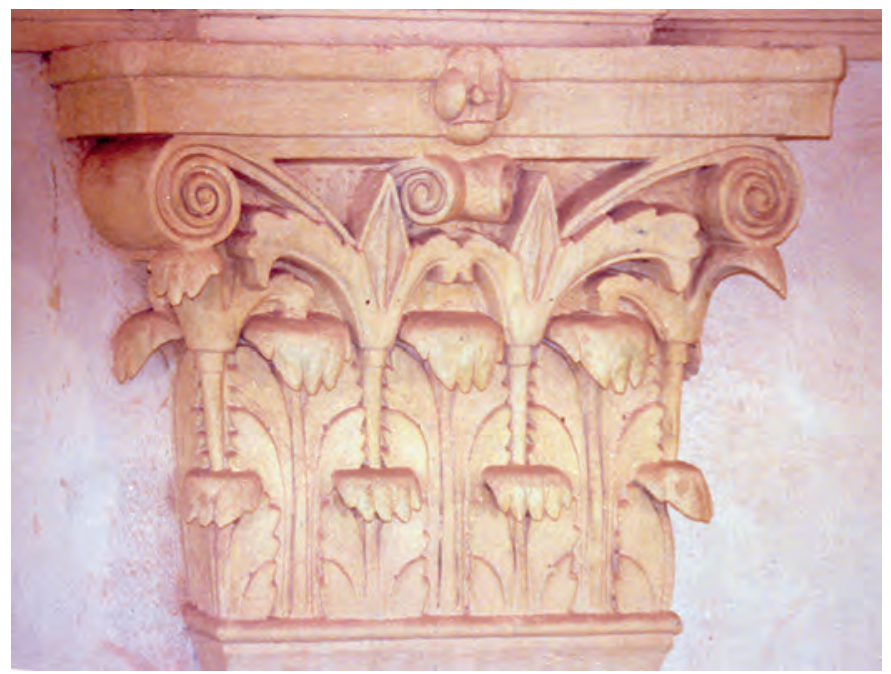

Capitel del interior. Fotografía ABN. 
Pilastras y entablamento estuvieron pintados formando estucos jaspeados, y el resto contaba con un enfoscado cuy a pintura simulaba despiece de sillares, según puede verse en una fotografía de principios del siglo XX.

Presenta un suelo de losas de már mol, blanco y grises formando damero en diagonal. En la cabecera vemos el presbiterio más alto que el resto de la nave, con cancela de hierro y una escalera en su centro para acceder al altar. Hay que destacar por último la existencia de algunos g rafittis de época, concretamente uno que esta situado detrás de uno de los altars y que quedó visible al desmontarse éste. El dibujo representa un personaje con barba y túnica que pudiera ser Jesucristo, San José o algún apóstol.

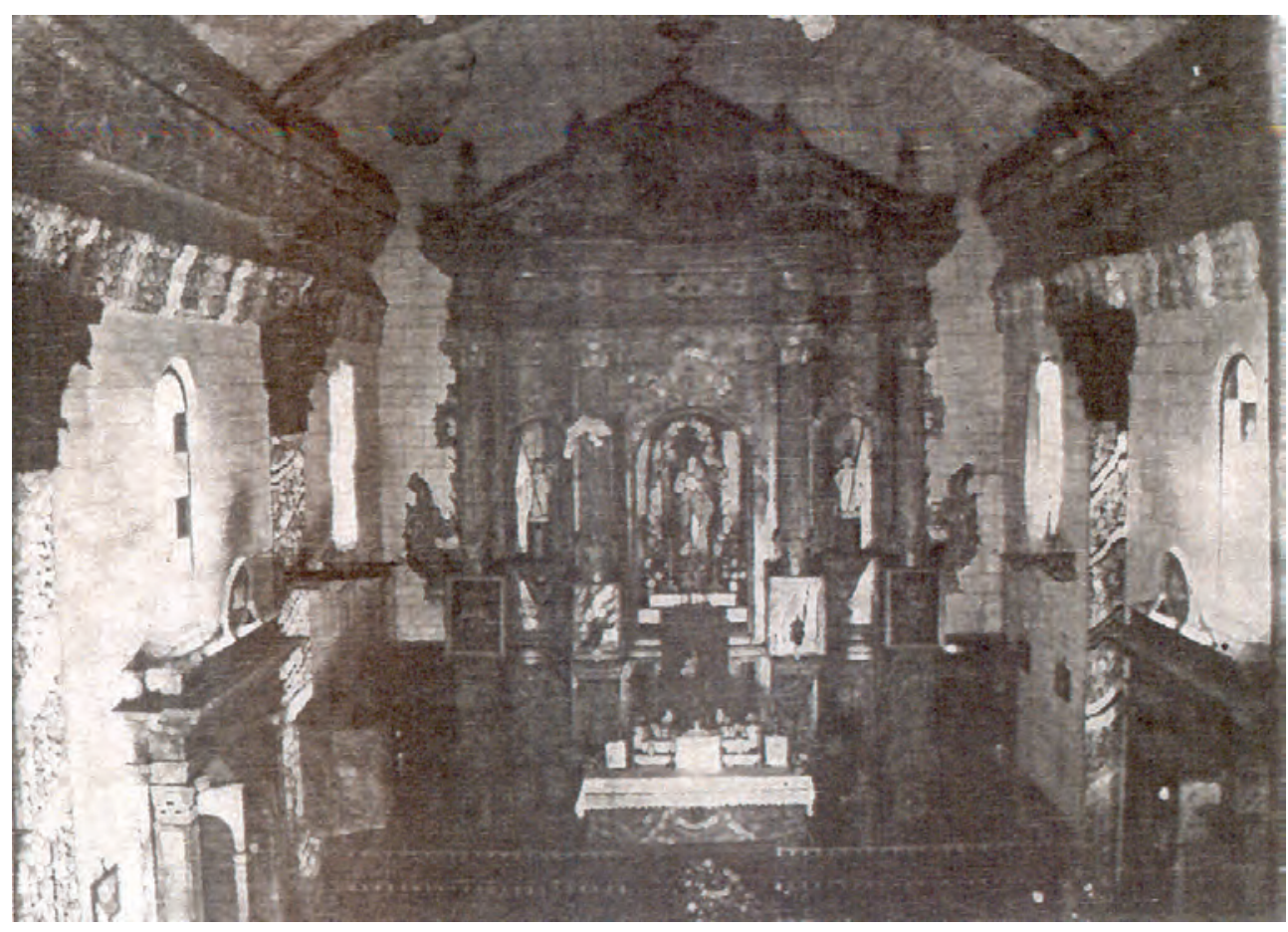

Fotografía del interior, principios del siglo XX. 


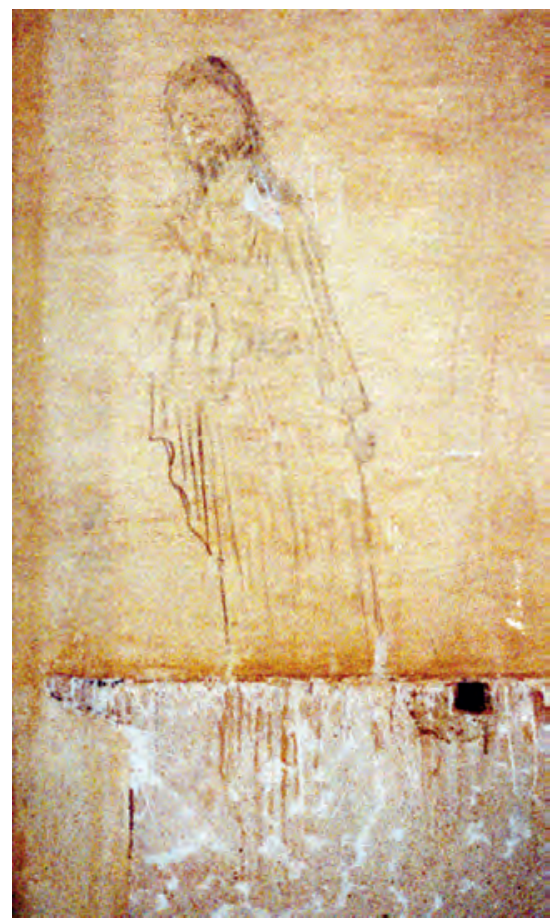

Graffiti encontrado tras un altar. 2005. Fotografía ABN.

\section{Mobiliario litúrgico: altares y retablo}

La iglesia de la Inmaculada Concepción de Chafarinas presenta un esquema iconográfico muy sencillo, basado en cua tro altares y un magnífico r etablo que es el que presenta mayor interés. También tiene un púlpito de madera con tornavoz adosado a la primera pilastra del lado del Evangelio.

Presenta 4 altares de madera, del que existen actualmente sólo tres. Son altares de formas muy clásicas, a modo de sencillos $\mathrm{r}$ etablos, situados bajo los ventanales, con pilastras de capitel compuesto sobr e basa y que contaban con peanas para situar las piezas escultóricas. Estos altares se encuentran en muy mal estado y su interés artístico es escaso.

Sin duda de mucho mayor interés es el retablo que se sitúa en la cabecera del templo. No conocemos ningún documento que nos permita conocer su autor, realización ni procedencia. Su estr uctura y base son clásicas, aunque los cornisamentos quebrados, el camarín y la decoración (sobre todo la inclusión de un elemento eminentemente barroco como la rocalla) nos lo situaría dentro del barroco español del siglo XVIII. 


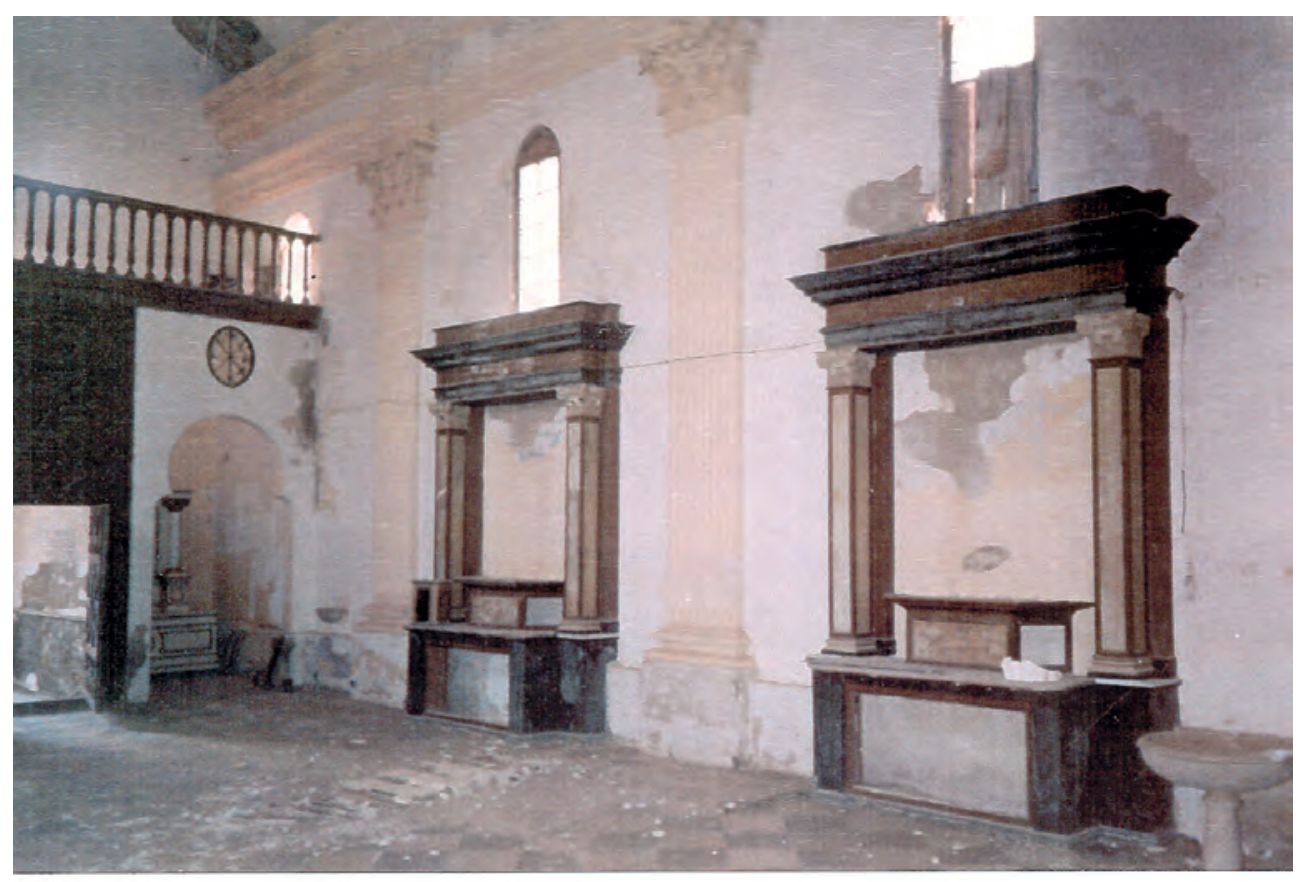

Vista de dos altares del lado del Evangelio, hacia 1992.

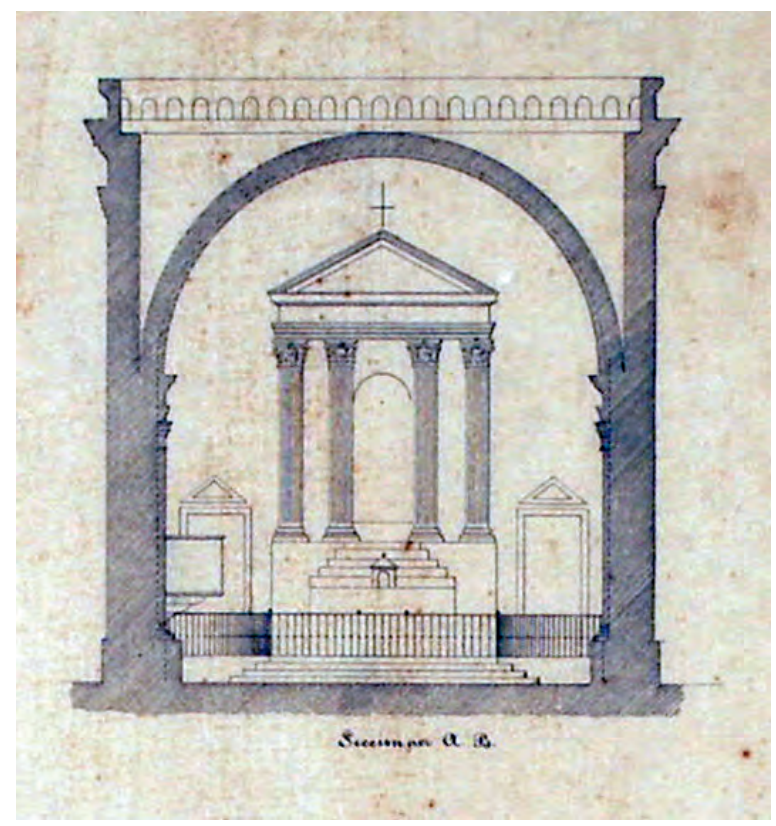

Dibujo del retablo, hacia 1862. IHCM. Melilla. 


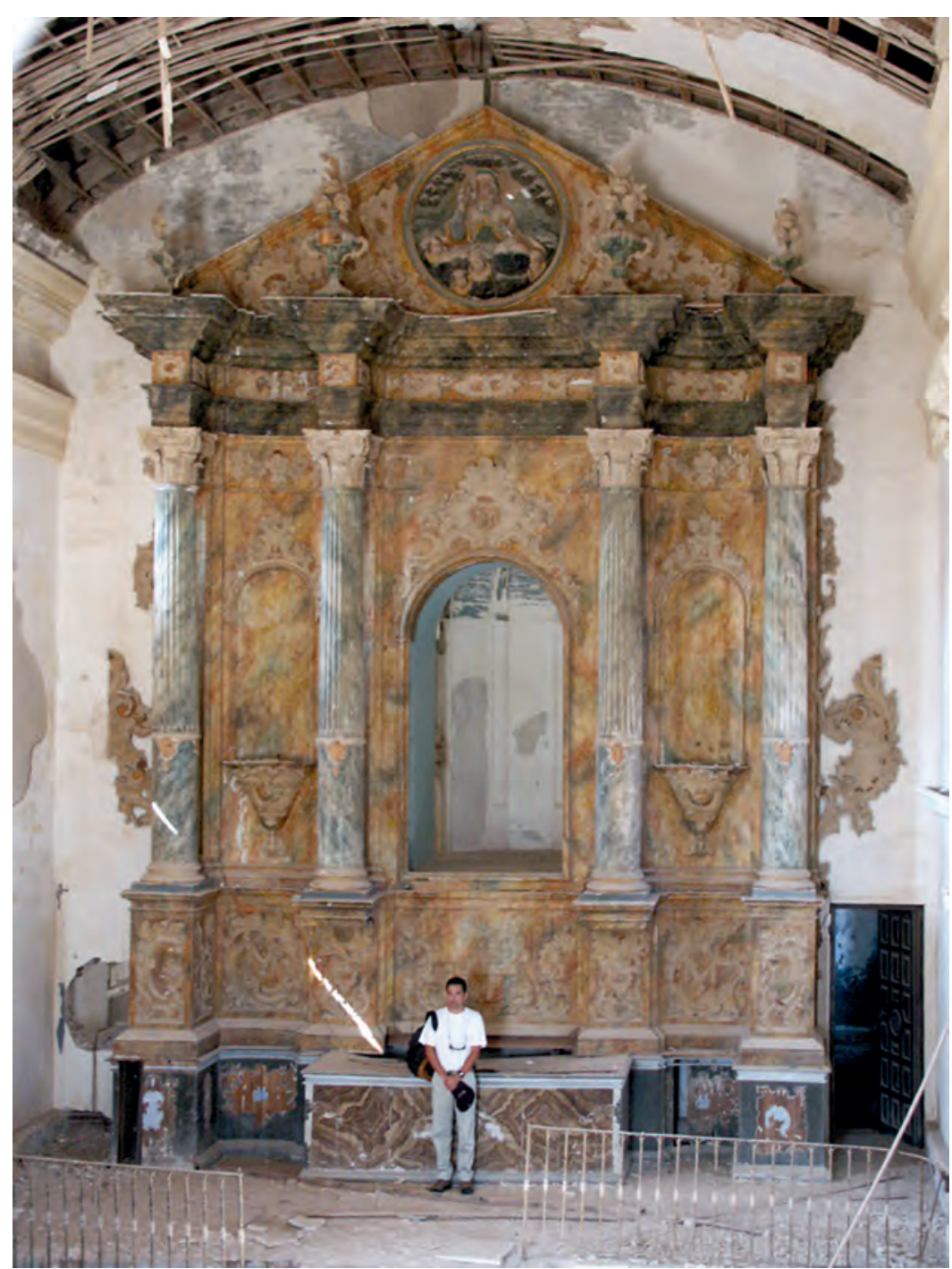

Retablo en una fotografía de 2002. Fotografía ABN.

El retablo tiene unas proporciones considerables, 9,5 metros de alto por 6,45 metros de ancho. Lo describiremos siguiendo el orden hor izontalmente, por pisos.

Arranca del cuerpo bajo o predela, tiene 0,97 metros de alto y actúa como zócalo a nivel del altar, de madera policromada de tonos oscuros, que tuvo adornos barrocos hoy arrancados. En su centro se sitúa el altar de madera jaspeada. 


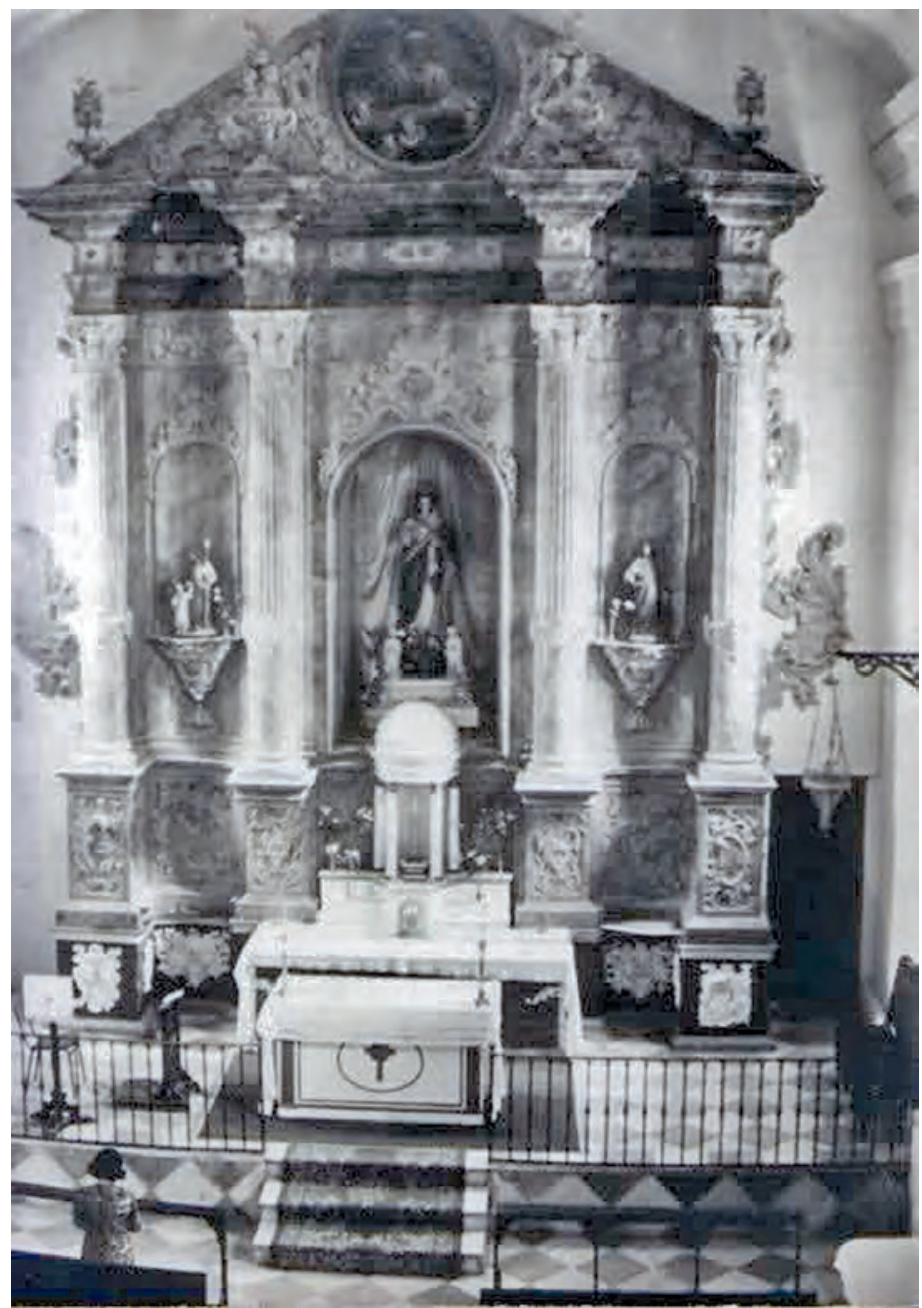

Fotografía del retablo de la iglesia de las islas Chafarinas. $S$ /f. http: / / mili-en-melilla.mi-web.es / fotosde-chafarinas-t2634-350.html

A continuación se sitúa el basamento, de 1,45 metr os de alto, y que actúa como base del orden. Presenta un friso decorado con entrantes y salientes al adaptarse al volumen de dos podium en los la terales extremos y de dos mensulones en la parte central que sirven de base para las cuatro columnas del retablo. La decoración es a base de rameados vegetales que se curvan en formas propias del barroco español del siglo XVIII, sin que haya referencias a otros motivos barrocos tan populares en España como las columnas salomónicas o a estípites y a geometrías quebradas. 

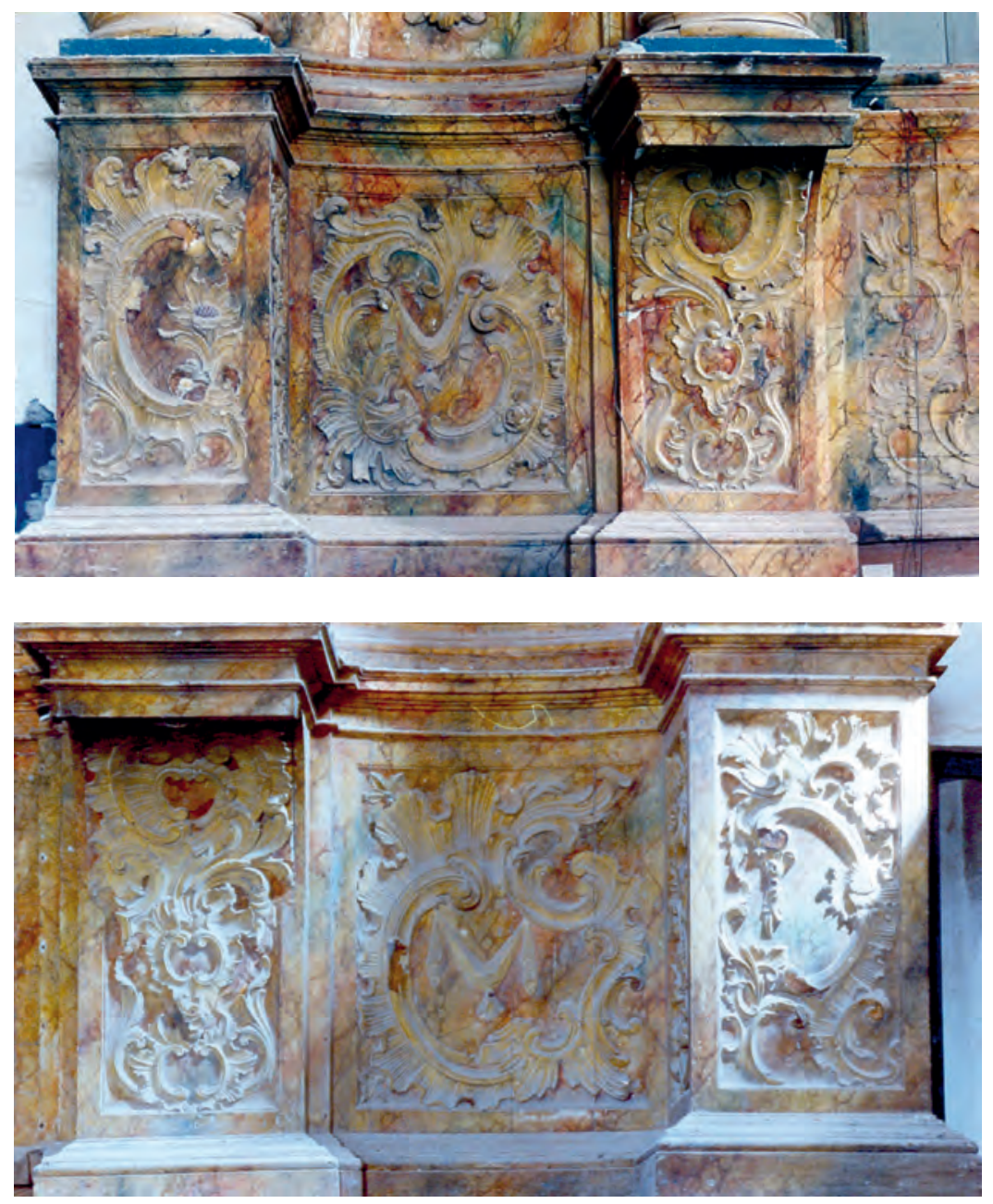

Basamento del retablo. 2002. Fotografía ABN.

Esta parte del retablo es muy característica del estilo barroco del setecientos, con múltiples detalles cóncavos y convexos. Esta pintado formando jaspes y mármoles, siendo un conjunto profuso y de gran belleza.

Para analizar la decoración escultórica de este piso, dividiremos la superficie en 11 relieves situados simétricamente de izquierda a derecha: los número 1, 2 y 3 cor responden al podium de la pr imera columna, el 4 cor responde a la entrecalle, el 5 al mensulón de la segunda columna,el 6 al paño central donde se situaba el manifestador, el 7 al mensulón de la tercera columnaẹl 8 a la entrecalle y 9,10 y 11 al podium de la cuarta columna. 
Todos los relieves citados son distintos entr e sí, lo que ofr ece una gran riqueza formal, y que describimos de forma individual:

El $1^{\circ}$, presenta una escena figura tiva, con casas $r$ ematadas con cúpula y castillete sobre rocas, al fondo un gran árbol con hojas y frutos. En la esquina se sitúa una nube de la que salen rayos de sol y en un lateral la rocalla barroca.

El $2^{\circ}$, motivo barroco de rocalla con flores, cuyas hojas se r etuercen en sinuosas curvas.

El $3^{\circ}$ También figurativo, muestra un grupo de casas con árbol de fondo y nubes con rayos de sol y motiv os rococó. Se encuentra incompleto al haber se arrancado parte de la decoración.
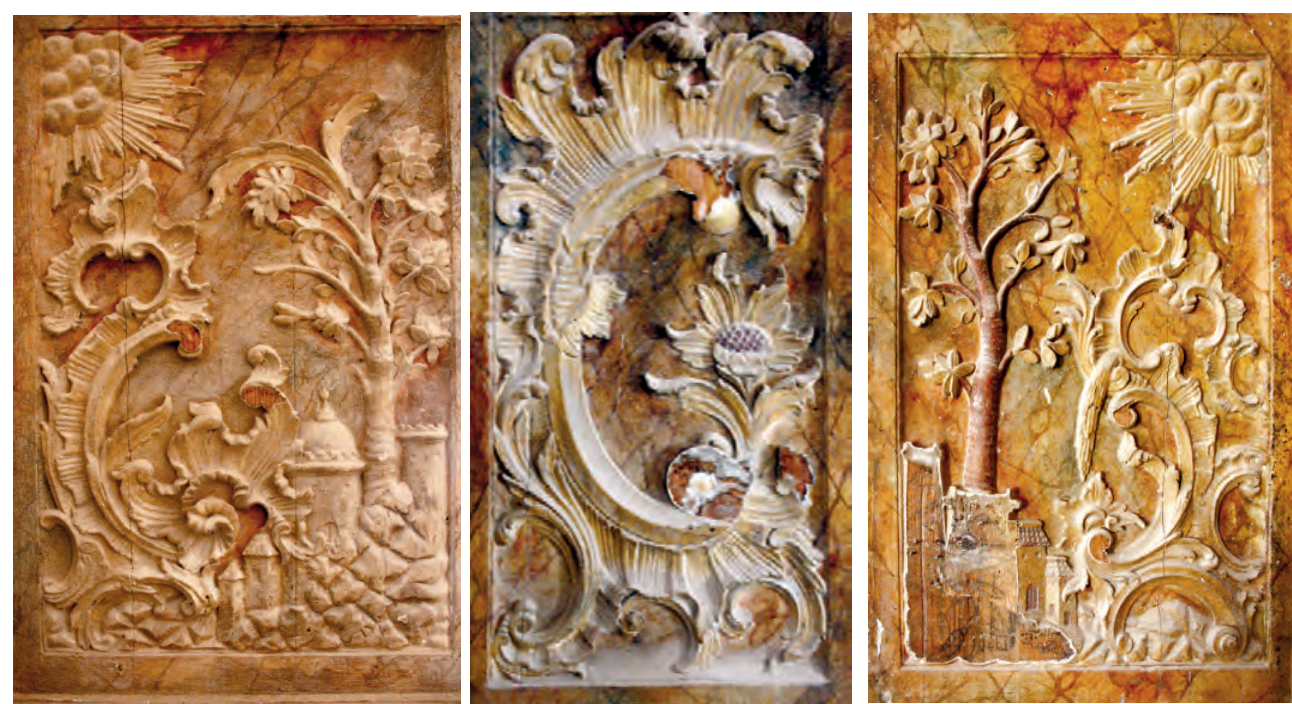

Relieves $n^{\circ} 1,2$ y 3. Fotografía $A B N$.

El $4^{\circ}$ relieve, muestra motivos de rocalla y cor tinas que se adaptan a una superficie cóncava, acentuando su bar roquismo y movimiento. El $5^{\circ}$, presenta detalles de rocalla contrapuesta adaptados a la curva de la ménsula. Destaca sobre todo la disposición casi simétrica de estos detalles.

El $6^{\circ}$, es un recuadro con decoración barroca que representa el centro del retablo, donde se sitúa el altar y manifestador $\mathrm{El} 7^{\circ}$, es el paño que se adapta a la curva de la ménsula, y presenta decoración de rocalla. Es bastante simétrico con el relieve número cinco. Finalmente el $8^{\circ}$, es una plancha con superficie cóncava a base de rocalla y motivos decorativos formando cortinas. 

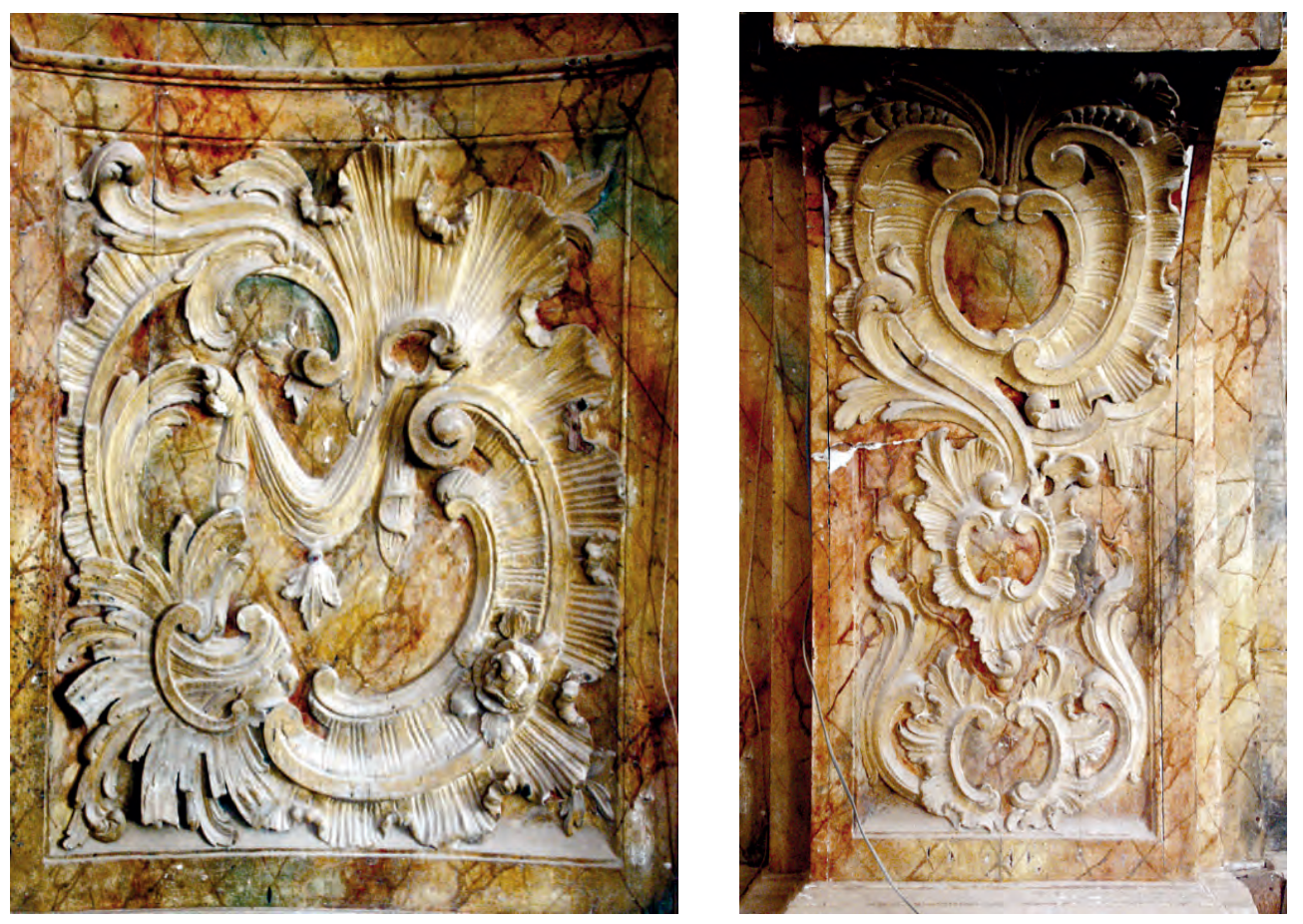

Relieves $n^{\circ} 4$ y 5. Fotografía ABN.

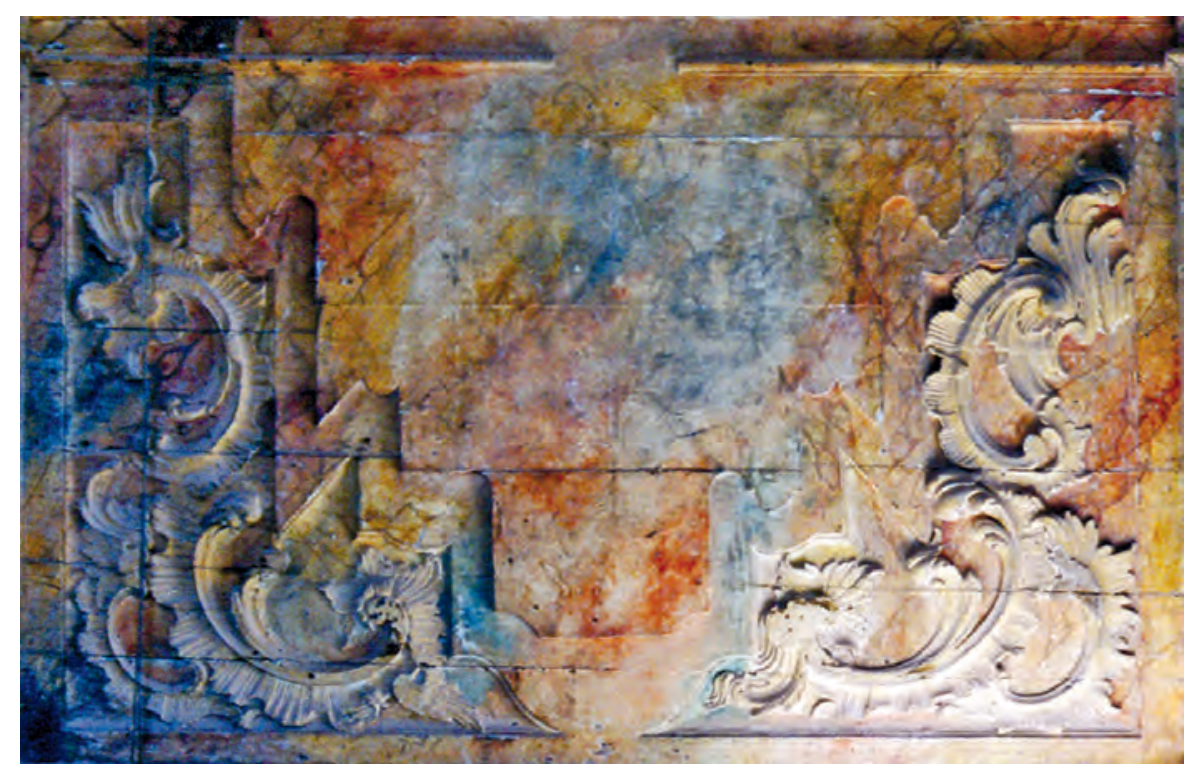

Relieve no 6. Fotografía ABN. 

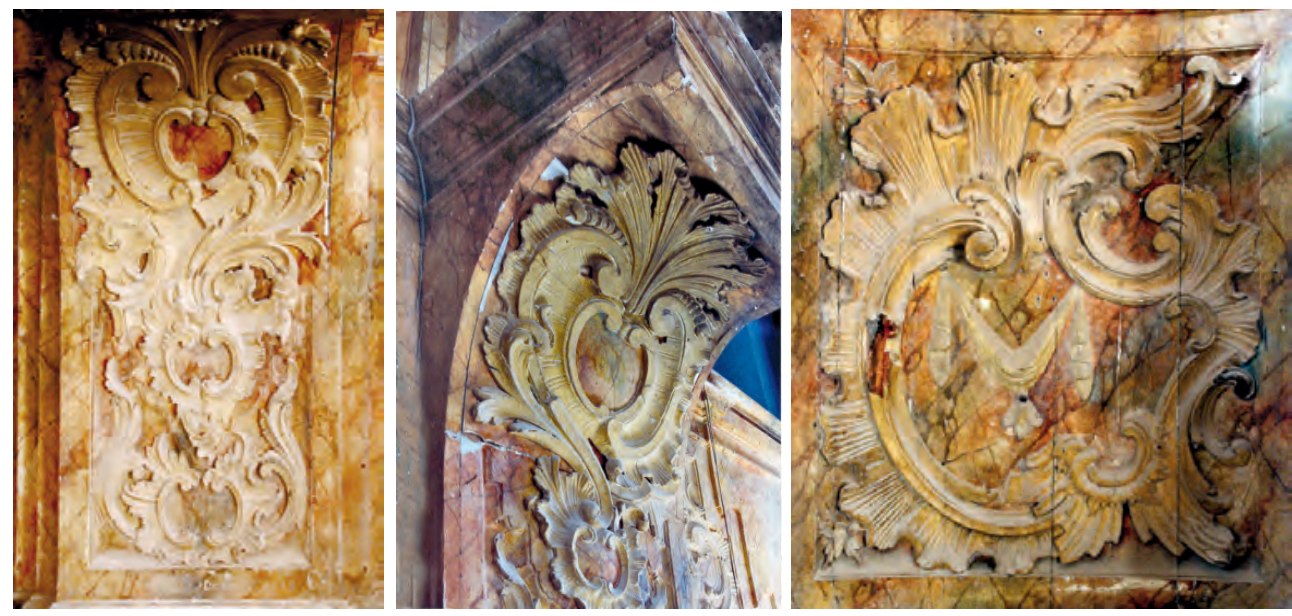

Relieves $n^{\circ} 7$ (frente y perfil) y 8. Fotografía $A B N$.

Los relieves $\mathrm{n}^{\circ} 910$ y 11 pr esentan decoración barroca de rocalla, típica del movimiento rococó, en la línea del resto del retablo.
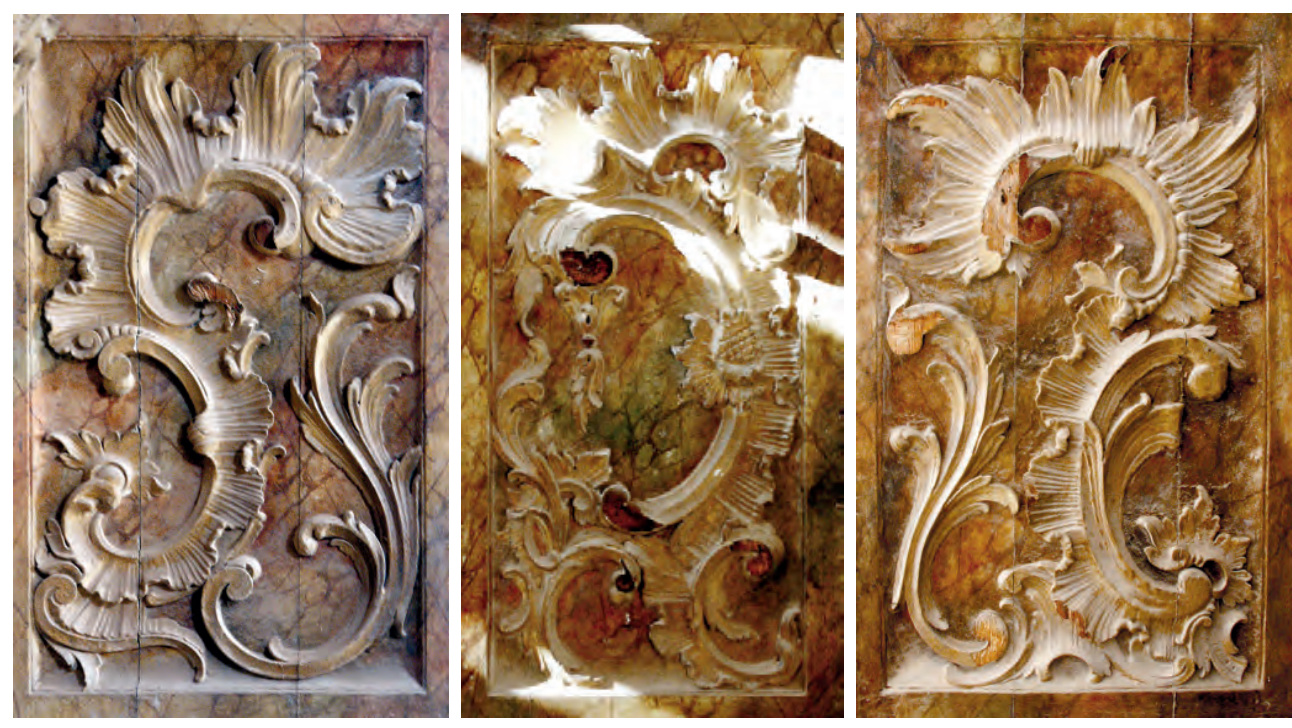

Relieves $n^{\circ}$ 9, 10 y 11. Fotografía ABN.

Finalmente, el retablo es cerrado en sus laterales por un cajeado vertical con flores y guirnaldas. 


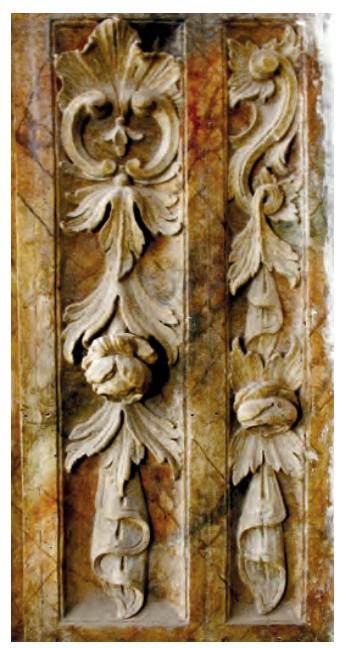

Cajeado lateral. Fotografía ABN.

La policromía se despliega por toda la superficie en tonos doradosyerdes, marrones sobre fondos jaspeados, dotando al conjunto de cierta vistosidad.

El orden propiamente dicho del retablo, de 4,22 metr os de alto, está formado por 4 columnas compuestas: tiene basa, fuste liso pintado con jaspes marmóreos en su primer tercio y acanalado en bisel en los dos tercios restantes hasta el capitel pintado de color claro.
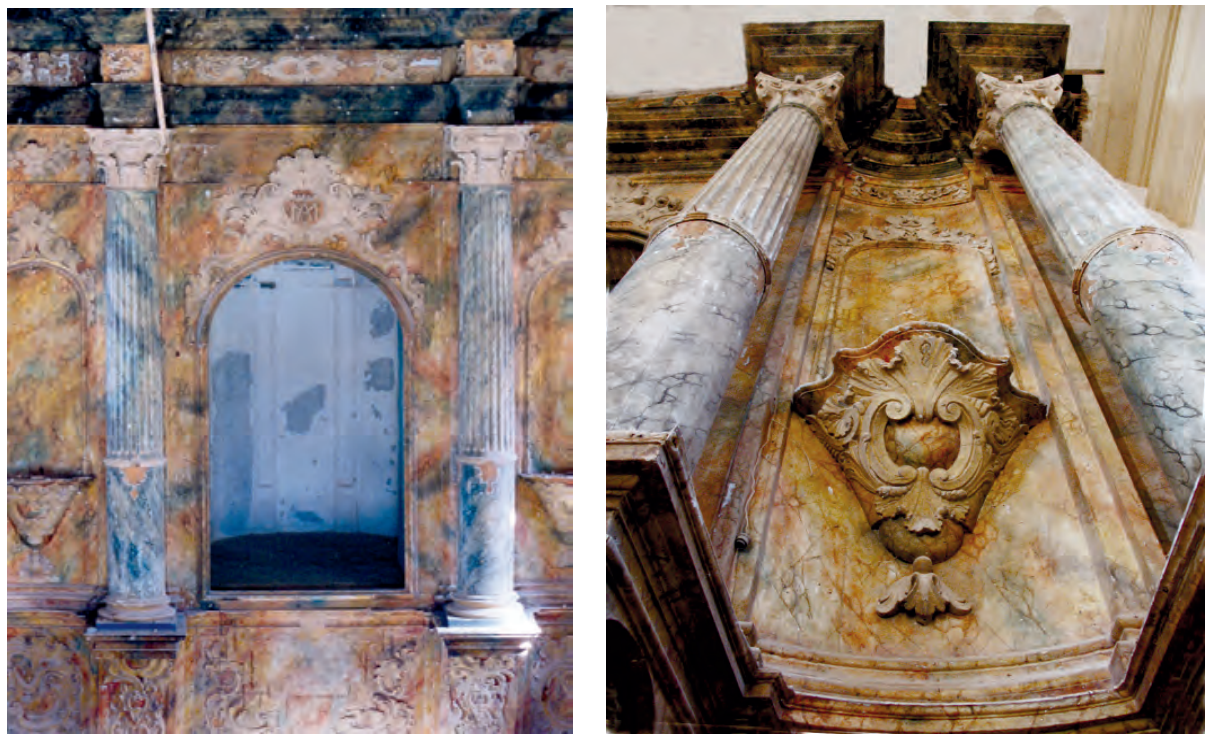

Detalles del orden del retablo, con sus columnas y entablamento. Fotografía ABN. 
El capitel es compuesto de corintio y jónico, con una única fila de acantos y cuatro volutas, pintado de tonos marmóreos claros. En los laterales del retablo arrancan adornos de madera con detalles de $r$ ocalla rococó que se extienden alegremente por la superficie.

Las columnas separan tres calles (verticales): una central en la que se abre el camarín con arco de medio punto de 1,5 metr os de diámetro. Sobre ella se establece un festón de decoración barroca con una cartela que tiene las letrasAM entrelazadas (el anagrama de María coronado). El acceso al camarín se realiza a través de unas escaleras laterales, en la sacristía posterior.

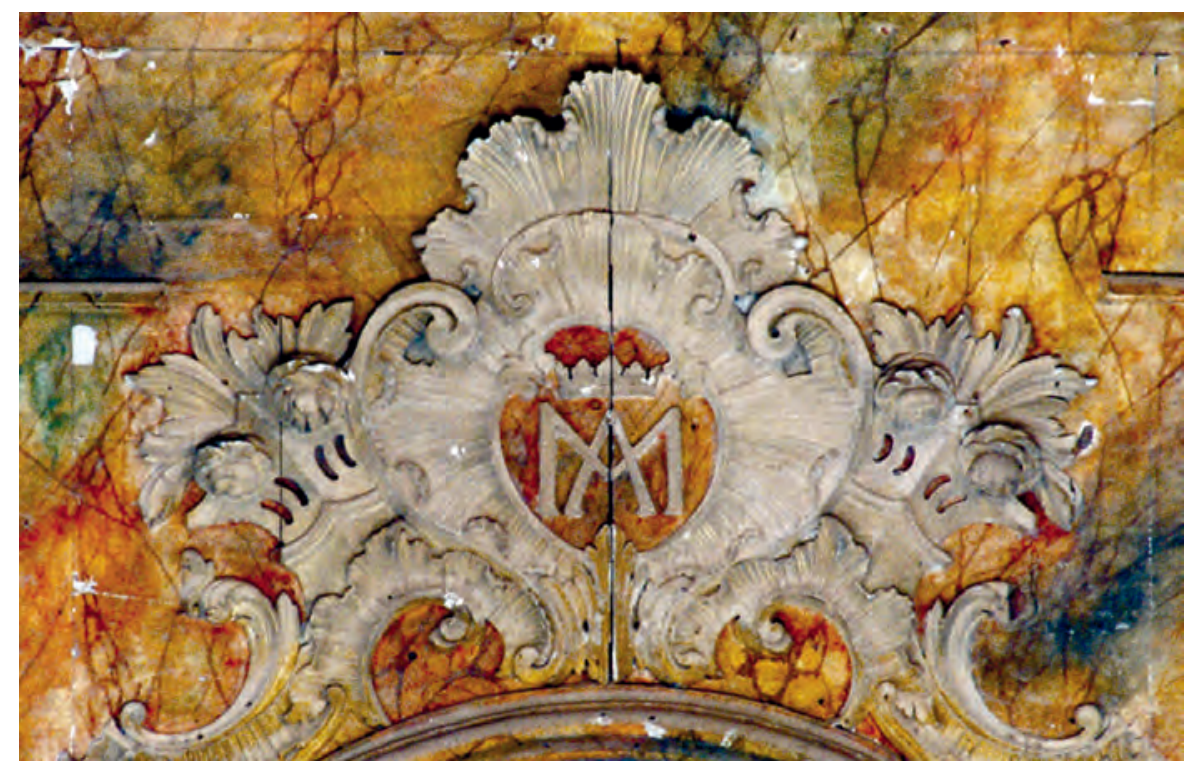

Placa barroca con el emblema de la Virgen maría coronada. Fotografía ABN.

Las calles la terales albergan sendas peanas-ménsulas de $g$ ran porte y elegante decoración carnosa (muy clásica: hojas de acanto y tor napuntas) que juega con los dorados sobre fondos marmóreos pintados. Estas peanas se asientan sobre una superficie cóncava que sirve para dar efecto visual a las figuras del retablo que debían estar en este lugar y que nos vuelv e a dar el tono barroco al conjunto. Esto queda potenciado por el juego entre claros y oscuros de los volúmenes entrantes y salientes.

Pero el mayor dinamismo se aprecia en el entablamento de 1 metro de altura, que se eleva sobre las cuatro columnas. Cromáticamente se establece una 
fuerte diferenciación horizontal entre cornisas pintadas en oscur o y frisos en claro. También se juega ampliamente con los cuerpos entrantes y salientes de las cornisas, creando efectos visuales de gran contundencia. Este cuerpo está rematado por jarrones de flores (rosas y azucenas alusivas a la pureza de laVirgen) que se elevan sobre cada columna subrayando el verticalismo y que potencian el dinamismo del conjunto.

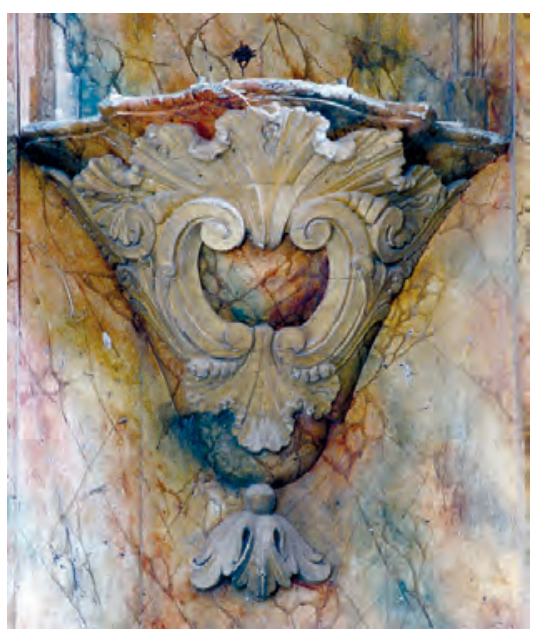

Peana. Fotografía ABN.
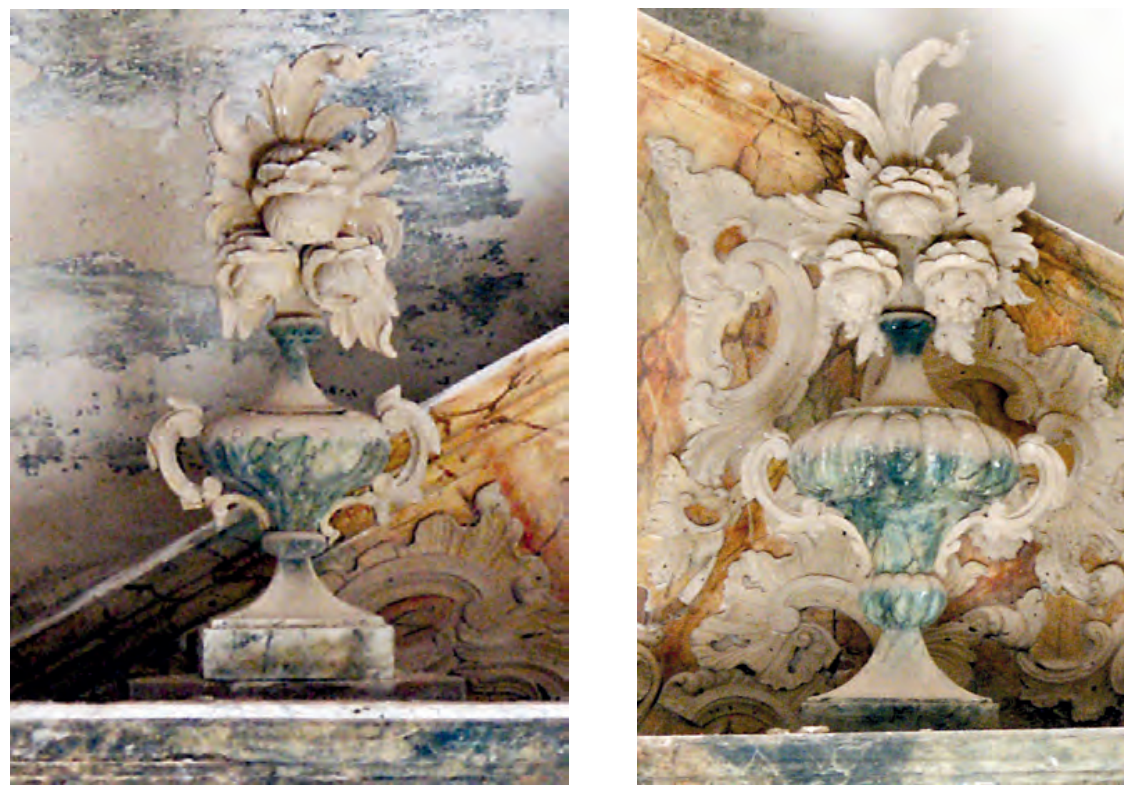

Detalle de los jarrones que coronan el entablamento. Fotografía ABN. 


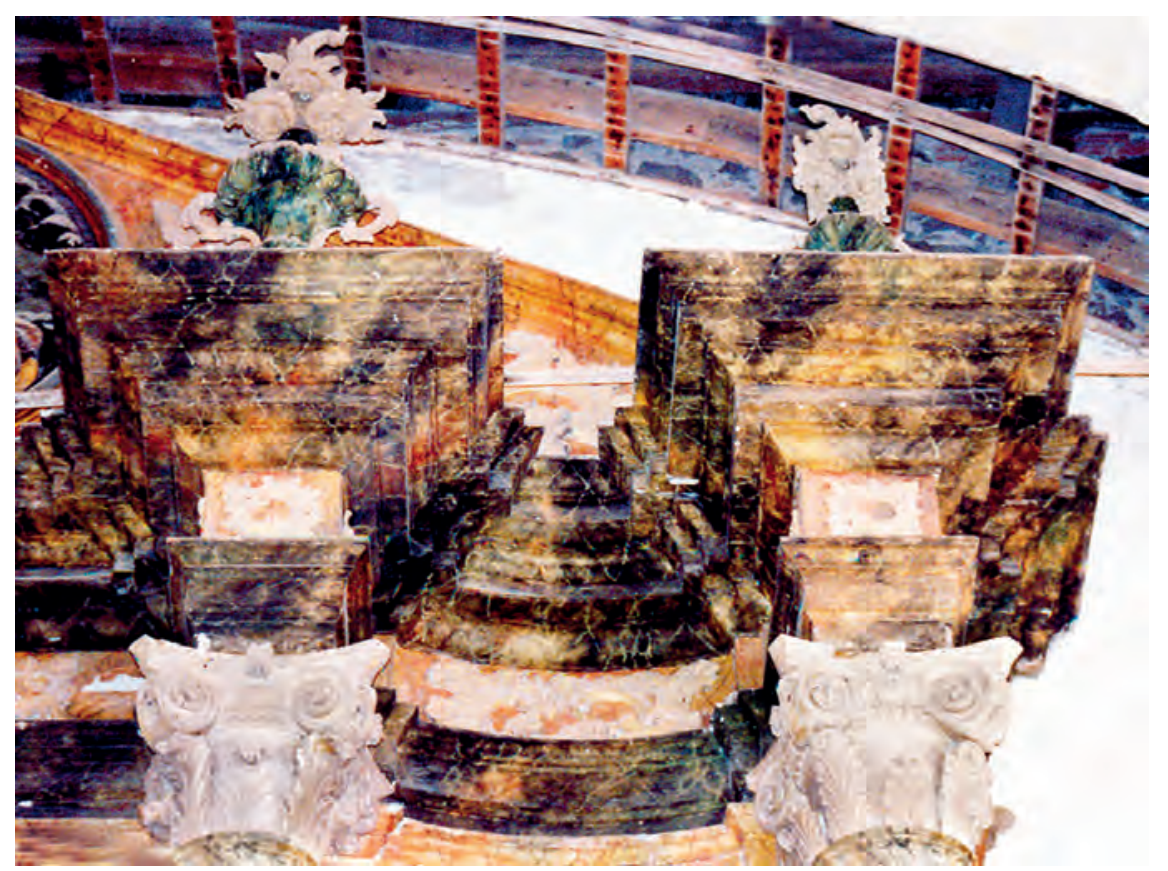

Detalle del entablamento. Fotografía ABN.

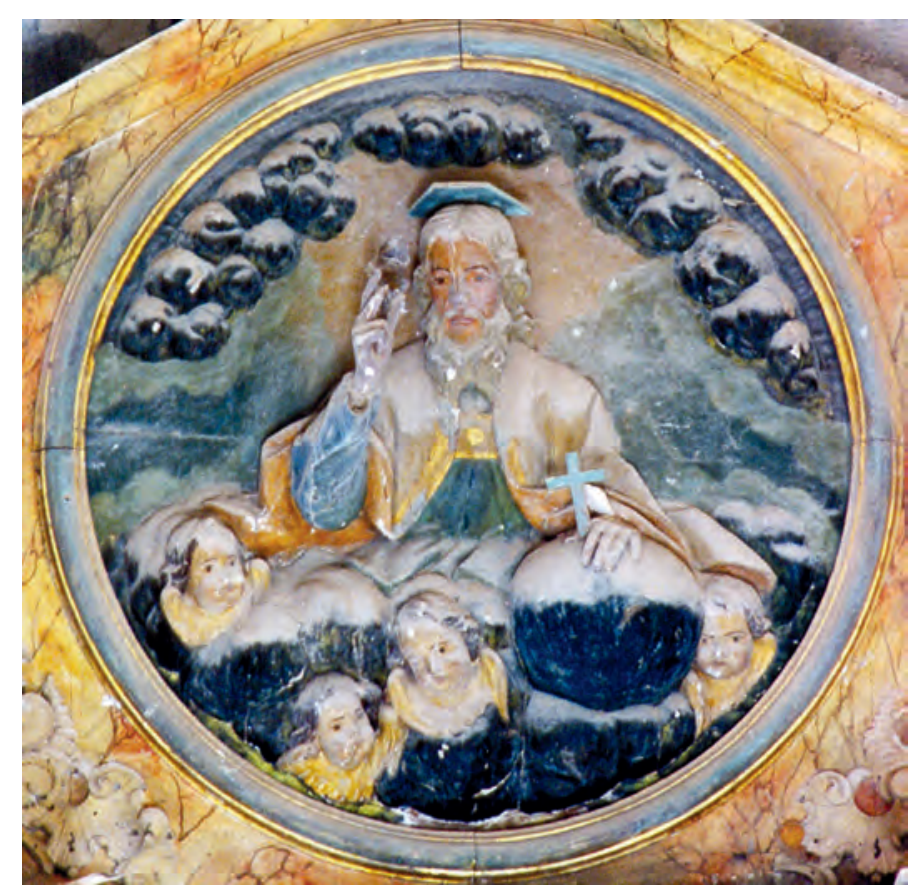

Tondo con la imagen de Dios Padre. Fotografía ABN. 
Finalmente el frontón se estructura en torno a un relieve policromado circular, tondo, de 1,5 metros de diámetio, con la figura de Dios Rdre, barbado, en actitud de bendecir mientras la otra mano la apoya sobre una bola que tiene una cruz, solución, la de este tipo de relieves en los frontones, muy clásica tomada de los retablos del siglo XVI. El conjunto descansa sobre nubes y destacan las cabezas de cuatro querubines. En el resto del tímpano aparecen nuevos detalles vegetales barrocos, rameados rococó que ocupan el resto del espacio.

Concluiremos señalando que el conjunto es de una gan armonía y sobre todo elegancia, lo que lo caracteriza como la principal obra de arte mueble de la isla.

\section{Programa iconográfico de la iglesia}

El templo se dedica a la Inmaculada Concepción,pero el programa iconográfico del retablo principal resulta algo confuso. Lógicamente estuvo presidido en su camarín por una talla de esta Virgen, y a su derecha e izquierda, sobre las peanas, figuraron dos imágenes de ángeles (en algunas fotos antiguas se apr ecia sin embargo la existencia de $\mathrm{v}$ arias esculturas de pequeño tamaño). Por otra parte ya hemos visto que un tondo con relieve de Dios Padre entre querubines remata el conjunto, y citaremos también una imagen pequeña del Sagrado Corazón de Jesús junto al altar.

Este programa iconográfico resulta algo pobre, sobre todo teniendo en cuenta la monumentalidad y envergadura del retablo, por lo que parece indicar que no fue totalmente completado y ha estado sometido a div ersos cambios y modificaciones, previos a la ausencia total de imágenes que presenta hoy día.

En los dos altares de la Epístola se situaban la figura del Nazareno (junto al presbiterio) y a continuación el Crucificado. Mientras que en los del Evangelio, el primero era la figura de la Doloısa o Piedad y a continuación el de la Virgen del Carmen, protectora de los manineros y gentes del mar. Finalmente, en el baptisterio se situaba la talla de San Juan Bautista.Tampoco hay que olvidar la imagen escultór ica del Sag rado Corazón de J esús en la fac hada de la Iglesia.

Vemos así imágenes relacionadas con la pasión y muerte de Jesús: Nazareno, Piedad y Crucificado, con otras de Dios Padre y Sagrado Corazón de Jesús, y con vocaciones popularmente arraigadas como la de la Virgen del Carmen. 


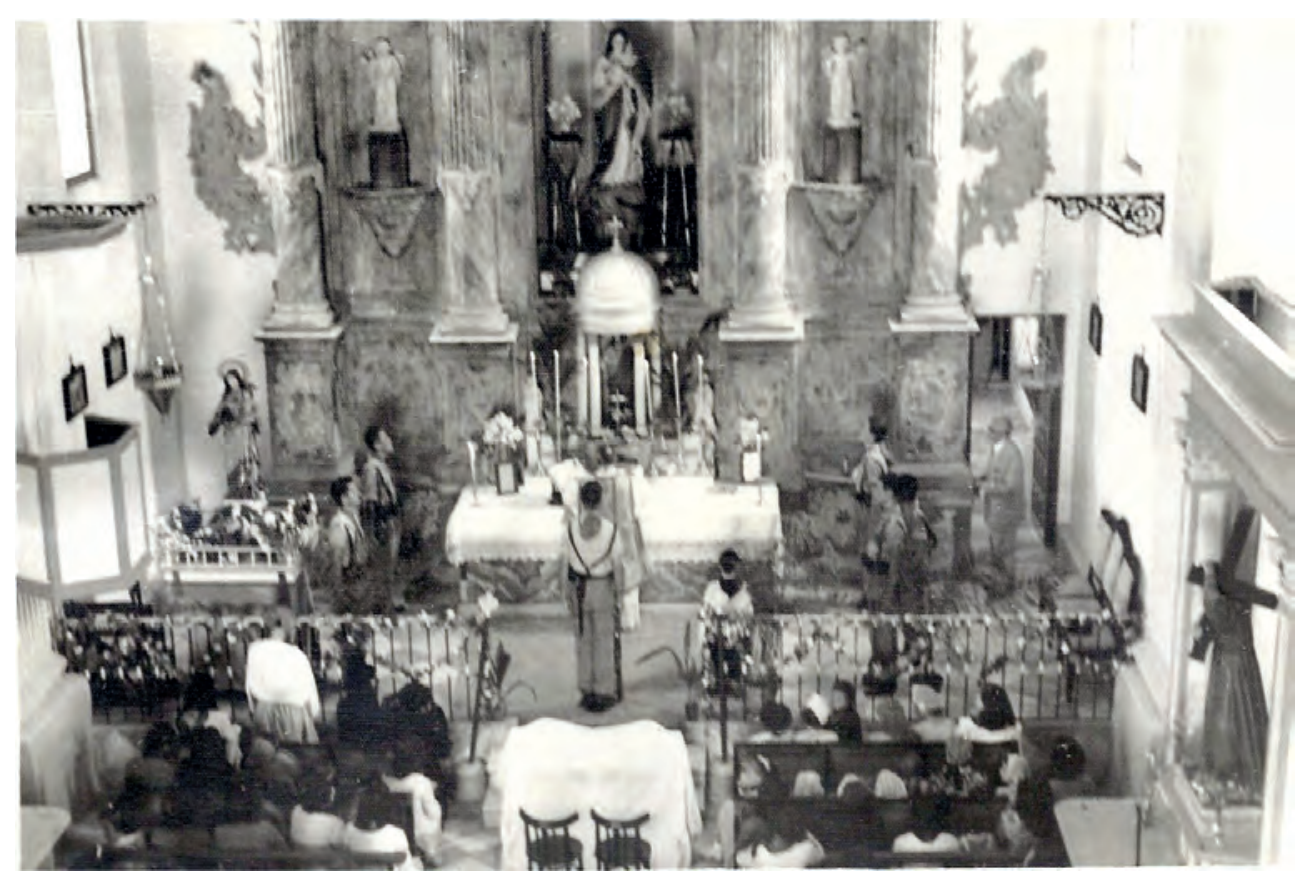

Imagen del interior, hacia 1952. ACML.

En cuanto a las imágenes y tallas, actualmente todas fuera de la isla, ha sido realmente dificultoso su estudio, debido a la dispersión sufrida por ellas desde la desafectación de la iglesia.

La Inmaculada Concepción se encuentra actualmente en el acuatelamiento de la Legión de Melilla. Es una imagen policromada en la que resalta el blanco y azul del manto, y dorado en los bordes. Realizada en el siglo XIX, continúa el modelo general barroco de las Inmaculadas de Alonso Cano, aunque ese acercamiento de las manos al pec ho es muy propio de la estética del XVIII. También muestra la característica serenidad clásica que elude el extremo barroquismo.

La Dolorosa o Piedad es del siglo XIX,y resulta una buena talla policromada de laVirgen con los brazos suplicantes alzados (modelo malagueño del siglo XIX) que combina la expresividad barroca con una gran serenidad. Se encuentra actualmente en la iglesia Castrense de Melilla.

Por su parte, la Virgen del Carmen, fue cedida a la iglesia de las islas Chafarinas por el armador José Jorro Andreu en 1912. 


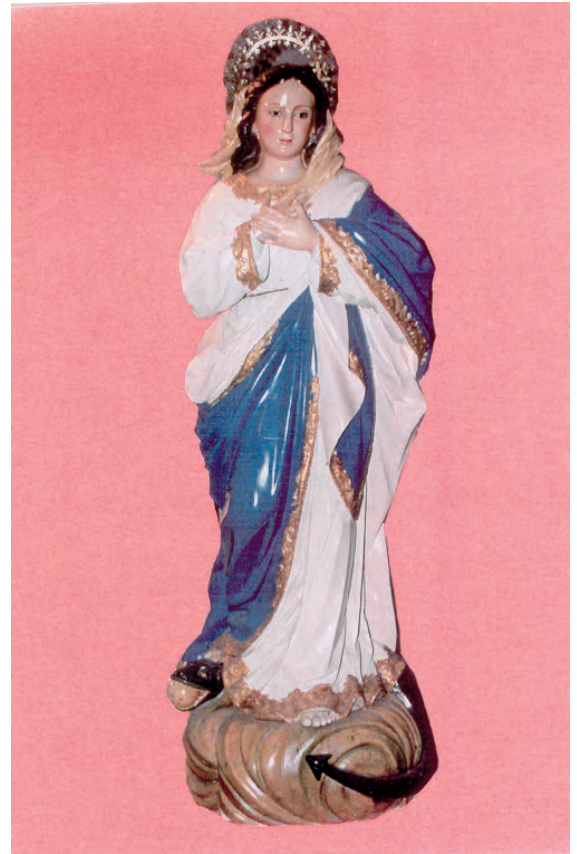

Inmaculada Concepción

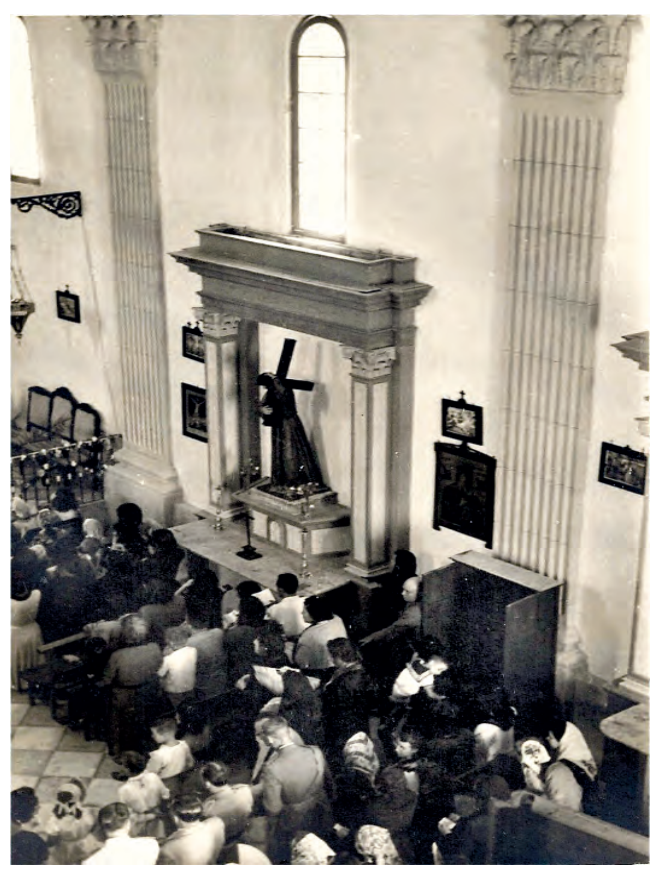

Vista del altar del Nazareno. ACML., 1952 y Nazareno en la actualidad.

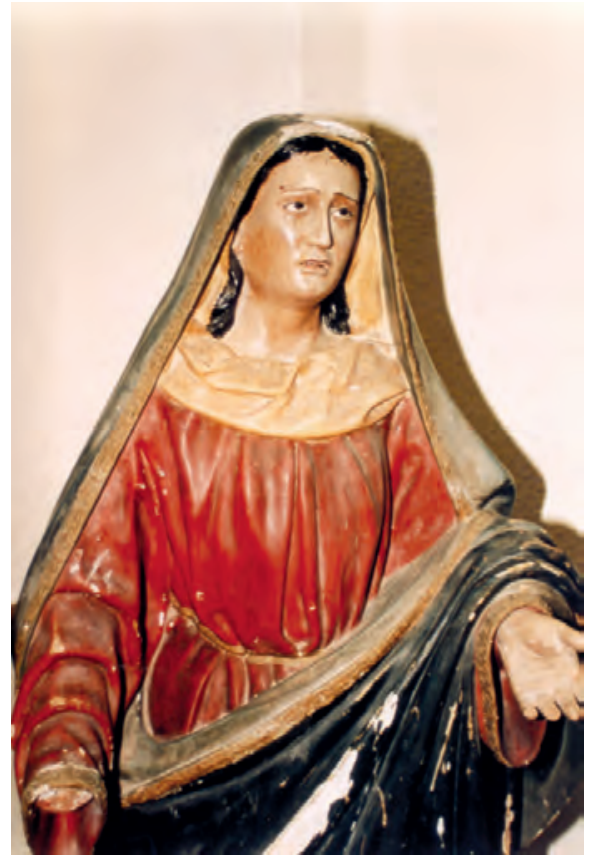

Dolorosa.

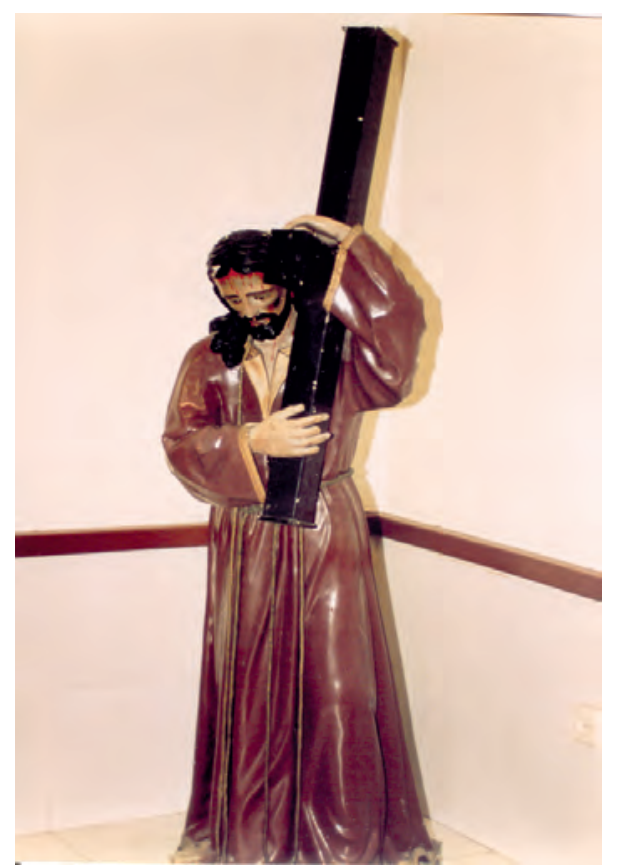


El Nazareno es una talla policiomada completa, no de vestir, que presenta un Cristo barroco y efectista, con túnica marrón y efectos visibles de la pasión en el rostro. La imagen es del siglo XIX, aunque obedece a un modelo muy repetido en el barroco español y actualmente se encuentra en la iglesia Castrense de Melilla.

De finales del siglo XVIII o pr incipios del XIX es el Cr ucificado de talla policromada, con el paño de pureza atado a la izquierda. Tiene un buen modelado del cuerpo, según modelo andaluz del siglo XVII. Se encuentra actualmente en la Parroquia de la Medalla Milagrosa de Melilla.

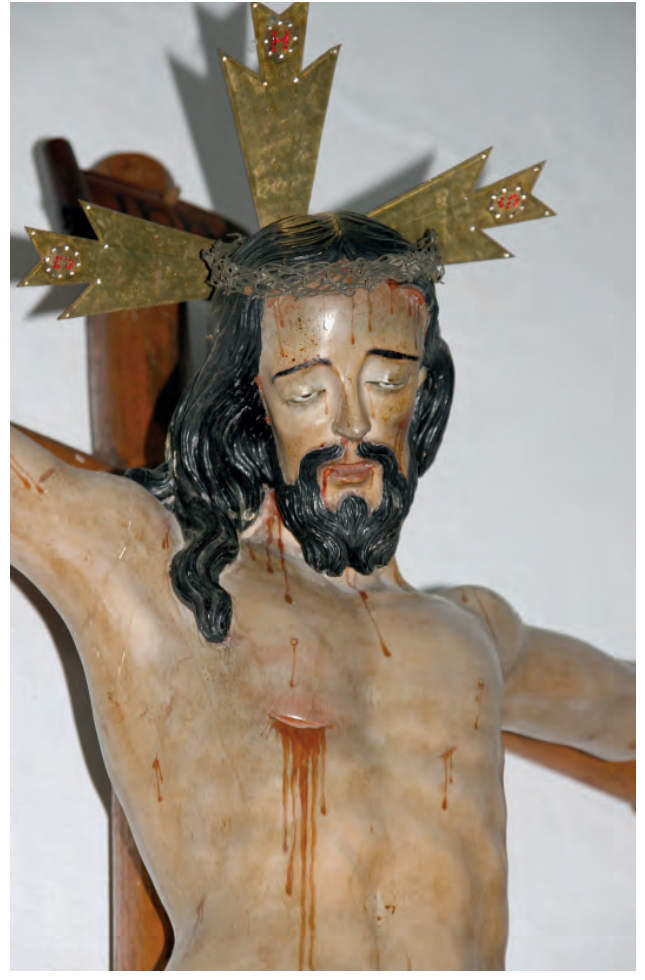

Crucificado. Foto Miguel Gómez Bernardi.

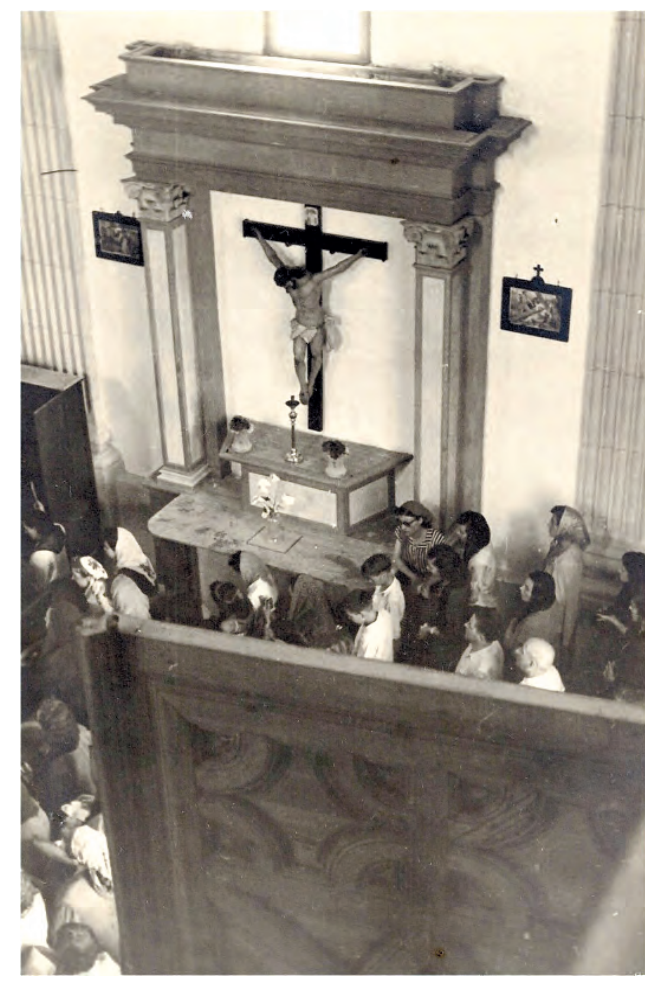

Crucificado en su altar, 1952. ACML.

Finalmente, el San Juan Bautista es una talla policr omada de tamaño mediano, de finales del siglo XVIII o pr incipios del XIX, que representa al santo, conservándose actualmente en el Museo Sacro de Melilla.

Podemos concluir señalando que a pesar de que esta iglesia y su imag inería corresponden a la segunda mitad del siglo XIX, y por tanto sigue las pautas compositivas propias de la tradición neoclásica, los modelos que encontramos 
son casi todos procedentes de la tradición barroca española de influencia andaluza. El carácter clásico y lo bar roco se funden en una obra singular constr uida en un contexto militar que refleja perfectamente la función para la que fue construida.

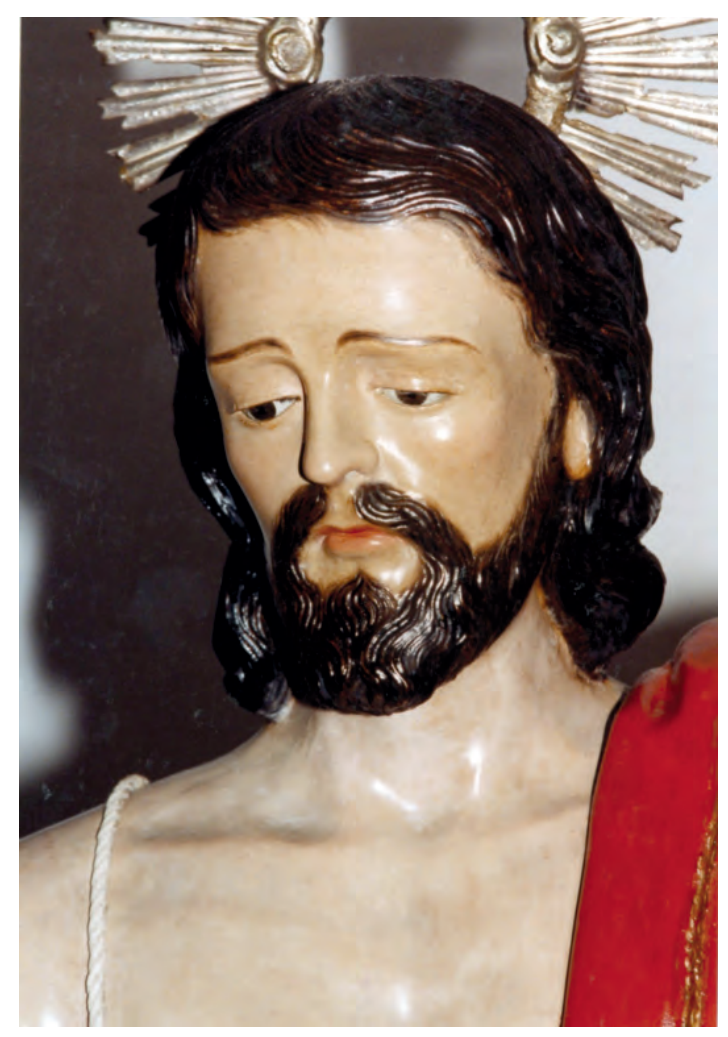

San Juan Bautista.

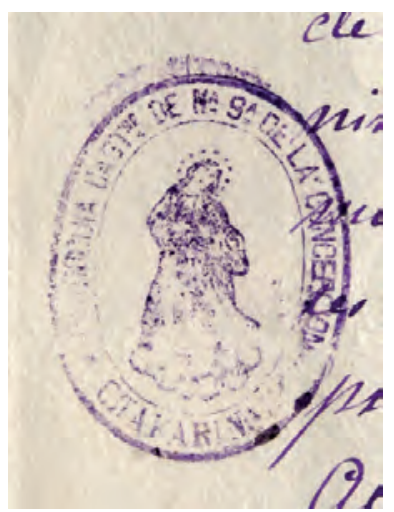

Sello de la Parroquia Castrense de Nuestra Señora de la Concepción, 1904. FCOML. 